\title{
メチル水銀，水銀およびセレンに関する研究動向 一疫学研究を中心に一
}

\author{
苅田 香苗 $*^{1}$, 坂本 峰至 $*^{2}$, 吉田 稔 $*^{3}$, 龍田 希 $*^{4}$, 仲井 邦彦 $*^{4}$, 岩井 美幸 $*^{5}$, \\ 岩田 豊人 $*^{6}$, 前田 恵理 $*^{6}$, 柳沼 梢 $*^{7}$, 佐藤 洋 $*^{8}$, 村田 勝敬 $*^{6}$ \\ *1 杏林大学医学部衛生学公衆衛生学教室 \\ *2 国立水俣病総合研究センター \\ *3 八戸学院大学健康医療学部 \\ *4 東北大学大学院医学系研究科発達環境医学分野 \\ *5 国立環境研究所環境リスク・健康研究センター \\ ${ }^{* 6}$ 秋田大学大学院医学系研究科環境保健学講座 \\ $*^{77}$ 尚絅学院大学総合人間科学部 \\ $*^{8}$ 東北大学名誉教授
}

\section{Recent Epidemiological Studies on Methylmercury, Mercury and Selenium}

\author{
Kanae KARITA*1, Mineshi SAKAMOTO*2, Minoru YOSHIDA*3, Nozomi TATSUTA*4, \\ Kunihiko NAKAI*4, Miyuki IWAI-SHIMADA*5, Toyoto IWATA*6, Eri MAEDA*6, \\ Kozue YAGINUMA-SAKURAI*7, Hiroshi $\mathrm{SATOH}^{* 8}$ and Katsuyuki MURATA*6 \\ *IDepartment of Hygiene and Public Health, Kyorin University School of Medicine \\ *2Department of Epidemiology, National Institute for Minamata Disease \\ ${ }^{*}$ Hachinohe Gakuin University Faculty of Health and Medical Care \\ ${ }^{*}$ Development and Environmental Medicine, Tohoku University Graduate School of Medicine \\ ${ }^{* 5}$ Centre for Health and Environmental Risk Research, National Institute for Environmental Studies \\ ${ }^{*}$ Department of Environmental Health Sciences, Akita University Graduate School of Medicine \\ ${ }^{*}$ Shokei Gakuin University Faculty of Comprehensive Human Sciences \\ *8Tohoku University Graduate School of Medicine
}

\begin{abstract}
More than sixty years has passed since the outbreak of Minamata disease, and high-level methylmercury contaminations now seem nonexistent in Japan. However, mercury has been continuously discharged from natural sources and industrial activities, and the health effects on children susceptible to methylmercury exposure at low levels, in addition to mercury contamination from mercury or gold mining areas in developing countries, become a worldwide concern. In this article, we provide a recent overview of epidemiological studies regarding methylmercury and mercury. The following findings were obtained. (1) Many papers on exposure assessment of methylmercury/mercury have been published since the Minamata Convention on Mercury was adopted in 2013. (2) The most crucial problem is child developmental neurotoxicity resulting from prenatal exposure to methylmercury, but its precise assessment seems to be difficult because most of such effects are neither severe nor specific. (3) Several problems raised in birth cohort studies (e.g., whether IQ deficits due to prenatal methylmercury exposure remain when the children become adults, or whether the postnatal exposure at low levels also causes such adverse effects in children) remain unsolved. (4) Concurrent exposure models of methylmercury, lead, polychlorinated biphenyls, aresenic, and organochlorine pesticides, as well as possible antagonists such as polyunsaturated fatty acids and selenium, should be considered in the study design because the exposure levels of methylmercury are extremely low in developed countries. (5) Further animal experiments and molecular biological studies, in addition to human studies, are required to clarify the mechanism of methylmercury toxicity.
\end{abstract}

Key words: methylmercury（メチル水銀）, elemental mercury（金属水銀）, selenium（セレン）, child development（小児発達）, gold and mercury mining（金・水銀鉱山） 


\section{1.はじめに}

水俣病の発生から早 60 年が経過し (1-5), 日本で水 俣病のよらな重大な健康影響が危惧されるよらな高濃度 のメチル水銀污染は起こらないであろら。しかしながら， 世界に目を向けると, 自然界に加光産業活動からの水銀 排出はむしろ増加傾向にあると考学られて打り（6），火 力発電所からの化石燃料の燃焼に伴ら水銀蒸気の大気へ の放出抒よび湖沼への蓄積や，中国，ブラジル，東南ア ジア，アフリカなどに打㤝小規模水銀鉱山や金採掘で の水銀污染掞よびそのメチル化の問題が現存する。また, 胎児や小児に打ける低濃度メチル水銀曝露の健康影響に 関する問題は必ずしも全て解決している訳でない。この ような観点から，低濃度曝露を含めたメチル水銀（およ び金属水銀）曝露による健康影響（症候，症状，各種検 査結果）に関する最新情報を逐次收集・整理していくこ とが重要となる。

2013 年 10 月に熊本で「水銀に関する水俣条約 (Minamata Convention on Mercury)」が採択・署名された $(6,7)$ 。こ れは, 2009 年にナイロビで開催された第 25 回国連環境 計画（UNEP）管理理事会で交わされた水銀によるリス ク削減のための法的拘束力のある「水俣条約」制定に向 けた議論を受けてのことであった。条約では，1）水銀 のリスクに対する認識や国際的な水銀対策の推進と必要 性，水銀対策を進める際の基本的な考方方を記載し，2） 水俣病の教訓として水銀污染による人の健康扣よび環境 への深刻な影響, 水銀の適切な管理の確保の必要性抢よ び同様の公害の再発防止を嵒い，3）污染者負担原則括 よび “予防的アプローチ”（8）を宣言したリオ原則が記 されている。この意義は，i）先進国と途上国が協力し て水銀の供給, 使用, 排出, 廃棄等の各段階で総合的な 対策に取り組むことにより, 水銀の人為的排出を削減し， 越境污染をはじめとする地球規模の水銀污染の防止を目 指し，ii）世界最大の水銀利用・排出国である中国や， 化学物質や廃棄物に関する条約をこれまで批准していな い米国を含め, 多くの国の積極的な参加を確保しつつ, その中で水銀のリスクを最大限低減できる内容の条約に 合意し, iii）“Minamata”を冠したのは「水俣病」と同様 の健康被害や環境破壊を繰り返してはならないといら決 意と, こうした問題に直面している国々が対策に取り組 む意志を世界で共有したことであった。

低濃度メチル水銀曝露に関する用量一反応（影響） 関係については, セイシェル小児発達栄養研究に携 わっている Strain ら（9）が， $n-3$ 多価不飽和脂肪酸 ( $n-3$ polyunsaturated fatty acids, PUFA）の影響を調整すると,

受付 2016 年 4 月 16 日, 受理 2016 年 6 月 27 日

Reprint requests to: Katsuyuki MURATA

Department of Environmental Health Sciences, Akita University Graduate School of Medicine, 1-1-1 Hondo, Akita 0101-8543, Japan

FAX: +81(18)836-2608

E-mail: winestem@med.akita-u.ac.jp
胎児期メチル水銀曝露と小児神経発達の低下との間に関 連があったと 2008 年に報告し, 多くの研究者が低濃度 のメチル水銀であっても神経毒性があると考えるように なった。しかし，この胎児期神経影響の可逆性/非可逆 性, 毒性機序, 個別臓器への影響など未解決の問題は山 積している。その上，先進国に颃いては水銀を含む多く の有害物質のヒトへの曝露濃度が低下して打り, 出生コ ホート調査などでメチル水銀/水銀の単独曝露モデルを 用いて解析することに研究デザイン上の問題が投げかけ られている。事実, 神経毒性や発達影響はメチル水銀だ けでなく, 鉛, ヒ素, ポリ塩化ビフェニル (polychlorinated biphenyls, PCB）などでも報告があり（10-15)，一方，前 述の PUFA だけでなくセレンもメチル水銀毒性に対し拮 抗的に作用する可能性が指摘されている $(16,17)$ 。

本稿では，既報の総説（4）以降のメチル水銀／水銀を 扱った論文を文献データベース Medline（PubMed）を用 いて検索し，(1)メチル水銀の曝露評価括よび途上国での 水銀污染の実態, (2) ヒトへの低濃度メチル水銀曝露によ る健康影響評価，(3)メチル水銀毒性を修飾する因子の評 価を要約し, 今後のメチル水銀研究に求められている課 題が何なのか探った。

\section{2. メチル水銀 / 水銀のヒト研究の推移}

メチル水銀（methylmercury）をキーワードとする総 論文数を 2004 年から 2016 年 1 月末まで PubMed で検索 すると， 1 年当たり $173 \sim 364$ 編（全言語）であり，こ のらちヒトを扱った論文数は $77 \sim 127$ 編 / 年であった (Table 1)。メチル水銀を扱った総論文数は徐々に増加し, 2004 年と比べると倍増している。これは, オープン・ アクセス誌の発刊が 2000 年以降急増 $(200 \sim 300 /$ 年 $)$ しているためと考觉られる（18）。2004年まではヒトを 対象とした研究は 4 割以上を維持していたが (4), 2005 年以降は 4 割に満たない。また, 2015 年はメチル水銀 関連論文のらち疫学研究の割合が著しく減った。同様に, 水銀（mercury）をキーワードとする論文数も 2 倍近く に増えた。このらちヒトを扱った水銀論文の割合は 4 割 未満であり， 2011 年以降は $30 \%$ 前後となっている。

低濃度メチル水銀曝露が小児神経発達に影響を及ぼす か否かを巡るフェロー出生コホート研究とセイシェル 小児発達研究の一大論争が $1998 ２ 000$ 年にあり (1924），これに伴い小児の神経発達影響に関する論文が多 数報告された。また， 2002 年に New England Journal of Medicine 誌上で成人に打故るチル水銀の冠動脈疾患り スクに関する議論が再燃し（25-27），世間を騒がせた。 混迷の続く中, 2008 年にセイシェル小児発達栄養研究 の成果が発表され $(9,28)$, フェロ一諸島とセイシェル のメチル水銀論争に一旦終止符が打たれ, メチル水銀に 関する関心も薄れてきたかのように思われる $(4,29)$ 。 一方, 環境省のエコチル調査 (30) を含め世界各地で種々 の化学物質を対象とした大規模な出生コホート研究が括 
Table 1 Numbers of scientific papers addressing "methylmercury" or "mercury" published in the period of 2004-2015, by means of PubMed of the US National Library of Medicine (accessed on 6, June 2016)

\begin{tabular}{|c|c|c|c|c|c|c|c|c|c|c|c|c|}
\hline & \multicolumn{12}{|c|}{ Year } \\
\hline & 2004 & 2005 & 2006 & 2007 & 2008 & 2009 & 2010 & 2011 & 2012 & 2013 & 2014 & 2015 \\
\hline Number of papers addressing "methylmercury" & 173 & 227 & 241 & 313 & 317 & 274 & 303 & 354 & 349 & 306 & 364 & 341 \\
\hline Number of human studies in them & 77 & 78 & 81 & 113 & 119 & 95 & 118 & 119 & 127 & 109 & 127 & 77 \\
\hline Proportion (\%) & 44.5 & 34.4 & 33.6 & 36.1 & 37.5 & 34.7 & 38.9 & 33.6 & 36.4 & 35.6 & 34.9 & 22.6 \\
\hline Number of papers addressing "mercury" & 983 & 1,240 & 1,327 & 1,422 & 1,504 & 1,440 & 1,577 & 1,745 & 1,779 & 1,767 & 1,930 & 1,877 \\
\hline Number of human studies in them & 374 & 398 & 440 & 456 & 505 & 435 & 511 & 535 & 532 & 551 & 584 & 414 \\
\hline Proportion (\%) & 38.0 & 32.1 & 33.2 & 32.1 & 33.6 & 30.2 & 32.4 & 30.7 & 29.9 & 31.2 & 30.3 & 22.1 \\
\hline
\end{tabular}

こなわれている。各国が独自の研究目的を掲げて立ち上 ゲたものの，実施を打ち切った国もあるが $(31,32)$ ，今 もって神経発達に影響するメチル水銀は見過ごせない化 学物質であり, 暫くの間はメチル水銀のヒトへの影響等 を扱った論文が報告されよう。また，2013年の「水銀 に関する水俣条約」の採択以後 $(6,7)$, ヒトへのメチル 水銀 / 水銀の曝露評価に関心が高まっている。

\section{3. メチル水銀 / 水銀の曝露評価}

Sheehan らは2014 年に “Global methylmercury exposure from seafood consumption and risk of developmental neurotoxicity: a systematic review”といら論文を発表した (33)。 同様のレビューは存在するが (34), これは「水銀に関 する水俣条約」の採択を受け，これまでに報告された魚 掑食集団のメチル水銀曝露レベルを地域枠で改めて要約 したものである。同時に, 各国にメチル水銀/水銀の曝 露評価を促すことを目的とした。したがって，今後数年 間はこの論文に沿ら形で, 各国 / 各地域の曝露濃度が測 定され，JECFA（FAO/WHO 食品添加物専門家会議）の 暫定耐容週間摂取量（PTWI）や米国環境保護庁（EPA） の参照值（RfD）を超過する度合いについて発表されよ ら。ここでは, Sheehan らの論文に引用されていない最 近報告された日本や中国をはじめとするアジア，米国， 中南米执よびアフリカに打けるメチル水銀/水銀の曝露 評価に関する研究を中心に要約する。

日本では魚が比較的高頻度に摂食され，メチル水銀の 主要曝露源は魚介類に限られる。Sakamotoらは胎児から 乳幼児までのメチル水銀濃度の他に重金属, セレン，ド コサヘキサエン酸 (DHA) 等の濃度を臍帯組織, 臍帯血, 母親の出産時頭髪 (以下, 毛髪), 出産時血液, 母乳, 手 足爪などから測定した（35-38）。このうち，無機水銀， メチル水銀, カドミウムなどを測定した研究によると, カドミウムおよび無機水銀濃度は臍帯組織に比べ胎盤組 織の方が各々 59 倍， 2.4 倍高かったが，逆にメチル水銀 濃度は胎盤より臍帯組織の方が 1.6 倍高かった (35)。つ まり，カドミウムの胎児移行に胎盤が強力なバリアとし て働いているのに対し, メチル水銀は胎盤で能動輸送さ れると考光た。また, 臍帯血の赤血球中総水銀濃度は母
体血と比べて 1.5 倍高かったが，3 ケ月の母乳摂取の間 に乳児赤血球中濃度は出生時の約 $60 \%$ に低下した (36)。 出産後に母親毛髪を $1 \mathrm{~cm}$ 間隔で測定すると, 臍帯血水 銀は頭皮から最初の $1 \mathrm{~cm}$ の毛髪水銀濃度と, また出産 時母体抢よび臍帯血漿 DHA 濃度は根元から $4 \sim 6 \mathrm{~cm}$ の毛髪水銀濃度と最も高い相関を示した（37）。さらに, 出産時母親の手足爪の水銀濃度は，臍帯血水銀濃度打よ び出産時母親毛髪 $(0 \sim 3 \mathrm{~cm}, 1 \mathrm{~cm}$ 刻久) の水銀濃度 と高い相関があった (38)。これらより，胎児のメチル 水銀は妊娠後期の母体のメチル水銀懪露を, また母体括 よび胎児の血漿 DHA レベルは妊娠中期の魚摂取を反映 し, その上臍帯血, 臍帯組織だけでなく, 出産直後の母 親の手足爪も胎児期メチル水銀懪露の推定に有用である と報告した。Iwai-Shimada らは生後 1 ヶ月時の日本人母 乳を測定し，総水銀に占めるメチル水銀割合は中央值で 54\%と報じた（39）。これまで母乳中水銀の殆どが無機 水銀と考兄られていたが, メチル水銀の摂取が多い場合 は，母乳中水銀の半分以上がメチル水銀であった。

中国の水銀鉱山周辺で大気，土壤，植物等の水銀污染 が報告され，大気や穀類を介したヒトへの健康影響が懸 念されている (40)。中国湖南・広東・貴州省の水銀鉱 山近辺から収穫期の稲を採取すると, 総水銀濃度は根, 軸と葉, 外皮, 玄米の順に高く, メチル水銀は根に次い で玄米で高く，玄米ではメチル水銀の総水銀に対する割 合も $30.9 \%$ と最も高かった $(41)$ 。貴州省水銀鉱山地域 の別報によると，米の総水銀拈よびメチル水銀濃度は 各々 $10 \sim 45 \mu \mathrm{g} / \mathrm{kg}$ と $3.2 \sim 39 \mu \mathrm{g} / \mathrm{kg}$ であり，土䁃中濃 度は层焼堆積物や尾鉱（選鉱屑）の近くが最も高く，米 のメチル水銀濃度と相関していた（42）。一方，中国の 3 水銀鉱山地域で収穫した水稲 26 品種の玄米中総水銀濃 度は $1.5 \sim 58 \mathrm{ng} / \mathrm{g}$ であったが，栽培品種により中国の 食品安全規格 $(20 \mathrm{ng} / \mathrm{g})$ 以下となり，栽培品種を適切に 選択すれば水銀蓄積量を低減できると報告した (43)。 中国から離れて，インドネシア Sulawesi 州 Palu 市近郊 の Poboya（金採掘）地域で 3 年間測定された 1 日平均 水銀蒸気濃度は Poboya 金処理地域で最も高く $(9,172$ $\left.\mathrm{ng} / \mathrm{m}^{3}\right)$, 市内 4 力所 3 日間の日中大気中水銀濃度も WHO 空気質ガイドライン值 $\left(1,000 \mathrm{ng} / \mathrm{m}^{3}\right)$ を超える 2,096 $3,299 \mathrm{ng} / \mathrm{m}^{3}$ であった (44)。水銀によるハザード指数 
(hazard quotient, HQ) は分析試料全体の 93\% が 1 を超光， 市民の大気曝露りスクが高いことが示唆された。

食品拱食によるリスク評価では，中国貴州省万山鉱山 地域の米食圈住民の血中抢よび毛髪中メチル水銀は米を 介したメチル水銀の 1 日推定摂取量と高い正の相関を示 乙, 毛髪/血液メチル水銀比は $361 \pm 105$ と, WHO が 魚摂食モデルで算出した比率 250 より (34), 高い值を 示した (45)。米国 Verginia 州でのアジア系が大多数を 占める 2 教会区の住民調査では, 魚介類摂食量と毛髪水 銀濃度との間に正の相関が見られ，平均毛髪水銀濃度は ベトナム系住民で $1.46 \mu \mathrm{g} / \mathrm{g}$, 中国系住民 $0.52 \mu \mathrm{g} / \mathrm{g}$ であり, 米国一般女性の $0.2 \mu \mathrm{g} / \mathrm{g}$ よりも高かった (46)。但し, モ ンテカルロ法で算出した年平均 1 日当たりのメチル水銀 摂取量はいずれも EPA の RfD $(0.1 \mu \mathrm{g} / \mathrm{kg}$ 体重/日）より も低かった。また, 米国の国民健康栄養調査 (NHANES) に基づくアジア系住民の調査では, 血中メチル水銀の個 人間変動の $21 \sim 23 \%$ が魚掑食頻度により説明できた (47)。韓国で市販の海産物分析值から推計された 1 週間 当たりの総水銀曝露は PTWI $(4 \mu \mathrm{g} / \mathrm{kg}$ 体重/週)の $2.59 \%$, メチル水銀は PTWI $(1.6 \mu \mathrm{g} / \mathrm{kg}$ 体重/週）の $1.82 \%$, EPA のメチル水銀 $R f D(0.7 \mu \mathrm{g} / \mathrm{kg}$ 体重/週) の $4.16 \%$ と, 安 全な範囲内にあった (48)。メキシコで市販の 23 海産物 中の 7 種およびッナ缶 9 種類のらち 5 種が EPA ガイド ライン值の $0.3 \mu \mathrm{g} / \mathrm{g}$ を超光, 妊婦のツナ缶, 新鮮魚, 貝 の月平均拱食回数から推計すると, $R f D$ を上回る母親が $29 \sim 39 \%$ もいた（49）。一方，上海市住民を対象に，水 銀をはじめとする有害金属（クロム，カドミウム，鉛， 七素), 有機塩素系殺虫剂, PCB, ポリ臭化ビフェニルェー テル, 多環芳香族炭化水素類の 1 日当たりの取込量を調 ベると，EPAリスク評価法に従った潜在的非癌性リス クは, 調査物質の中でメチル水銀が最も高かったが, 食 品からの污染物質摂取に対する複合 HQは 1 以下となり, 問題視されるレベルではなかった (50)。

水銀一金アマルガム法が用いられている南米小規模金 採掘場では，作業者や周辺住民への直接的な水銀蒸気曝 露に加え, メチル水銀を蓄積した魚介類の摂食による健 康影響が問題となっている。ブラジル Amazon 流域の Pará州の 2 つ金採掘地区に打ける採掘作業者のリスク 評価では，両地区で捕獲した魚類 66 検体のらち $22 \%$ 以 上が WHO 魚介類摂取規制値の $0.5 \mu \mathrm{g} / \mathrm{g}$ を超えており, 水銀曝露の HQ \& $1.5 \sim 28.5$ と高かった（51）。Amazon の Madeira 川流域は金採掘の他, 森林伐採, 水力発電所 ダムが環境に影響を及ぼすため, 川魚 84 種 3,182 検体 の総水銀とメチル水銀濃度が分析された (52)。食物連 鎖網の上位にいる魚食性・肉食性魚では総水銀濃度が平 均 $51 \sim 1,242 \mu \mathrm{g} / \mathrm{kg}$ と最も高く, メチル水銀/総水銀比 は $70 〜 92 \%$ に達して扣り，この地域の魚介類を摂食す ることで水銀生物濃縮の顕著な影響を受けたと考兄られ る。また, ブラジル Pantanal 湿地域の地元産魚 2 種の水 銀濃度は，WHO の規制值 $(0.5 \mu \mathrm{g} / \mathrm{g})$ を上回ってはいな かったが，魚介類を 1 日 6 オンス（約 $170 \mathrm{~g}$ ）以上摂食
する住民の食習慣から推計すると水銀摂取量は 0.49 $1.08 \mu \mathrm{g} / \mathrm{kg} /$ 日となり, 川辺の住民では推奨制限量を超え る状況にあった (53)。ブラジル以外では, コロンビア の San Martin de Loba 金採掘地区でリスク評価がおこな われ, 採掘地区住民の平均毛髪総水銀濃度は $2.12 \mu \mathrm{g} / \mathrm{g}$ (対 照地区は $0.58 \mu \mathrm{g} / \mathrm{g})$ であり，金採掘地域の土㙋蓄積性 指標（geoaccumulation index）は 6 を超光，極めて污染 度が高かった（54）。一方，コロンビアMojana 地域で金 採掘堆積物中の総水銀を 5 段階連続抽出法で調べた Pinedo-Hernández らは，その $48.4 \%$ が有機物と結合した 水銀であり，水溶性や胃酸可溶性水銀などの交換性水銀 の割合は $1.7 \sim 4.7 \%$ と低かったが, 水中で生物濃縮さ れると高い健康リスクとなり得ると述べた（55）。エク アドルでは, 水銀アマルガム法で金採掘されている Amazon 流域 Yacuambi 川の土壇中水銀濃度が測定され, バックグラウンド值より高濃度であるが，カナダ環境閣 僚会議の土䁃含有量基準值 $6.6 \mathrm{mg} / \mathrm{kg}$ より低いことが確 認された(56)。

アフリカのセネガルの小規模金採掘場のある Kedougou 地方では，水銀測定した地元産魚介類 8 種 32 検体中の 濃度は WHO 規制值 $(0.5 \mu \mathrm{g} / \mathrm{g})$ 以下であったが，甲殼 類 2 種 7 検体の全てが規制值以上 $(0.5 \sim 1.05 \mu \mathrm{g} / \mathrm{g})$ であっ た (57)。毛髪総水銀濃度は, 周辺住民 111 人の約 3 割 が EPA の参照用量 $(R f D, 1 \mu \mathrm{g} / \mathrm{g})$ を超えており，川魚の 摂取の久ならず水銀蒸気の直接曝露による影響が示唆さ れた。ナイジェリアのNnewiにある病院で沶こなわれ た母親一新生児 95 組の横断研究では，3 割以上の母親 が少なくとも日に 1 度は魚を食べ，かつ対象の $36 \%$ が $R f D$ 相当 $(5.8 \mu \mathrm{g} / \mathrm{L})$ を超劣る臍帯血中水銀濃度を有し, その水銀濃度は出生時体重, 身長, 頭囲叔よび胸囲と有 意な正の相関を示した $(58)$ 。

\section{4. メチル水銀の健康影響}

\section{1 神経発達影響}

フェロー出生コホート研究では, メチル水銀の胎児期 曝露が小児神経発達に影響することを報告してきた（19， 21-23，59-61)。2014 年にはフェロー諸島の子ども 176 名の臍帯血水銀のほか新たに臍帯血漿リン脂質中の脂肪 酸相対濃度を測定し，7歳時の言語，運動，注意，空間， 記憶に関する能力との関係を評価した（62）。California 言語習得テストの短期間想起はメチル水銀曝露が高くな るにつれて低下することが観察され，脂肪酸濃度を調整 するとこの関連性はさらに強固になった（\%変化= $-22.0 ; 95 \% \mathrm{CI} ，-39.4 \sim-4.62)$ 。脂肪酸濃度を調整し た構造分析モデルでも，記憶機能の低下はメチル水銀曝 露の増加と関連した $(\%$ 変化 $=-1.94 ; 95 \% \mathrm{CI},-3.39$ -0.49)。メチル水銀曝露影響を過小評価することのな いよう，調査ではPUFA を測定する必要性を説いた。ま た， $1986 〜 1987$ 年生まれのコホートでは出産時母親毛 髪と臍帯血水銀濃度の他に 7 歳抒よび 14 歳児の血液・ 
毛髪中水銀濃度も測定され, 視覚空間記憶指標と 7 歳児 血中水銀濃度の間に有意な負の関連が示された (63)。 これらの結果より, 異なる時点で得られる曝露情報を説 明変数に組久込む回帰分析では誤差が生じやすく, 胎児 期の曝露影響が過小評価され易くなると注意喚起した。 メチル水銀曝露による認知機能低下が成長しても続く のか検討するため, フェロー出生コホート研究では 22 歳コホート 814 名に対し神経心理検査を実施した (64)。 必要とされる共変量を全て調整すると, Boston 呼称検 査执よび他の言語能力検査の低得点が臍帯血水銀濃度の 上昇と有意に関連し, 個々の IQ 検査領域に対する共分 散構造分析モデルではいずれも負の関連が認められた。 特に言語性理解・知識とは関連が強く, 呼称検査では臍 帯血水銀濃度が 10 倍になると, 得点が 2.2 低下する結 果となり，胎児期メチル水銀曝露は認知機能に長期間影 響すると考兄られた。台湾の母子 83 組を追跡した調査 では, 認知, 言語, 運動発達の Bayley 発達検査 (BSID-III) と, 胎便中の総水銀, 3 歳児の毛髪, 手指爪, 足指爪の メチル水銀濃度との関係を検討した $(65)$ 。各メチル水 銀濃度は子ぞもの魚摂取量と正の相関があり, また BSID-III の表出コミュニケーション得点と負の相関を示 し, かつ 3 歳児の $70 \%$ が EPA の許容基準 $1 \mu \mathrm{g} / \mathrm{g}$ を超え る水銀量の魚を搷食していたことが表出コミュニケー ション能力低下のリスクと考光られた。ブラジルでは錫 鉱石採鉱地の Bom Futuro に住む子ども294 名を調査し， その中の男子 105 名で 6 ヶ月の認知発達指標 (BSID-II の中の MDI 得点）が家族収入拈よび出生体重と, また 2 歳時の MDI 得点が母親出産時毛髪水銀濃度と有意に 関連した (66)。また男子では歩行開始年齢が毛髪水銀 濃度および授乳期間と関係した。これょり，胎児期低濃 度メチル水銀曝露のある環境下では男児が認知発達の遅 滞に対して鋭敏であると示唆した。

セイシェル共和国の小児コホート研究では一連のメチ ル水銀影響について報告してきたが，神経発達に有意な 影響を及ぼすと結論したものはない。セイシェル小児発 達研究の 19 歳コホート533名の調査では, 検査時の毛 髪水銀濃度は男女全体で簡易知能検査（K-BIT）と負の 関連を示したが, 出産時母親毛髪水銀濃度は 19 歳コホー トの各種神経発達指標と何も関連しなかった（67）。ま た心拍変動の低下が胎児期のメチル水銀曝露と関連する ことが報告されているが $(59,68)$, セイシェル小児発達 研究の 19 歳コホート 95 名では圧反射感受性, 心拍変動 指標, RR 間隔比, 起立性低血圧のいずれも, 出産時母 親扣よび 19 歳コホートの毛髪水銀濃度と有意な関連を 示さなかった（69）。セイシェル小児発達栄養研究では, 出産後の母親の毛髪水銀, 血清アラキドン酸, DHA 值 を測定したが，20ケ月児 1,256 名で調べた Bayley 発達 検査 (BSID-II) や行動調査票による神経発達のいずれ の指標とも直接的な関連は見られず，有意な交互作用が メチル水銀と PUFA の間で BSID-II の運動発達指標 (PDI 得点）に対して見られた（70）。さらに母親の DHA 值は
言語発達と正の関係を，また認知発達指標とは負の関係 を示した。セイシェル小児発達栄養研究でのコホート 1,784 名に自閉症スクリーニング質問票（SCQ）調査が おこなわれたが (71)，子どもの性別や母子の年齢等を 考慮しても，毛髪水銀濃度と自閉症スペクトラムとの間 に有意な関連を認めなかった。また後者の 5 歳児コホー ト 236 名で金属水銀懪露指標として母親の歯アマルガム 装着数を調べ，小児神経発達検査指標との関連を検討し たが，出産時母親の毛髪水銀濃度と PUFA，社会経済指 標，性・年齢等を調整しても有意な関連は見られなかっ た（72）。因みにセイシェルでは，新生児 230 名の出生 時体重と妊娠 28 週および出産後の母体血 PUFA 濃度, 出産時毛髪水銀濃度との関係についても調査したが, 性・ 年齢や体格, 生活習慣, 社会経済状態, 既往歴などを調 整しても, メチル水銀拈よび PUFA と出生時体重との関 連は認められなかった（73）。

近年, メチル水銀の他に, $\mathrm{PCB}$ や有機塩素系殺虫剤 などの神経毒性物質を加えた疫学研究が実施されつつ ある $(14,15,74,75)$ 。Orenstein らは1993〜 1998 年間に 米国 Massachusetts 州 New Bedford の PCB 污染度の高い 港湾近くで生まれた学童 393 名の記憶・学習機能への 影響を記憶検査（Wide Range Assessment of Memory and Learning）により検討した（76）。母親の妊娠中の飲酒・ 哭煙習慣やPUFA 等を調整した重回帰分析の結果，毛髪 水銀が $1 \mu \mathrm{g} / \mathrm{g}$ 増加する毎に視覚性記憶は 2.8 点 $(95 \% \mathrm{CI}$, $0.6 \sim 5.0$ 点), 学習に関しては 2.2 点, 言語性記憶は 1.7 点低下すると予測されたが，臍帯血中 PCB やジクロロ ジフェニルジクロロエチレン（DDE）とは有意な関係 が見られなかった。

\section{2 循環器系影響}

メチル水銀の低濃度曝露が心筋梗塞や高血圧症と関連 することが示唆されているが, その証拠は限られている。 フェロー出生コホート研究で, Sørensen らは 1〜 $10 \mu \mathrm{g} / \mathrm{L}$ の臍帯血中水銀濃度が 7 歳児の血圧と有意な正の関係 を持つことを報告した (22)。過去にメチル水銀中毒の 発生した水俣市に沶いて，1953 年から 1970 年までの粥 状動脈硬化性心疾患の標準化死亡比（SMR）を算出す ると（77），1953～1967 年は一定して低かったが，逆に $1963 \sim 1967$ 年の高血圧症 SMR は 1.38 と有意に高く (95\%CI，1.06〜 1.79), その後低下した。これより Inoue らはメチル水銀曝露が高血圧を引き起こしたと述べた。 これに対し，米国内のコホート調査では妊娠中期の血中 水銀濃度と 3.2 歳伃よび 7 歳児の収縮期血圧の間に有意 な関係は見られなかった（78）。同様に，米国大規模コ ホート（男女 6,045 名）の足爪を収集後平均 14.9 年追跡 した Mozaffarian らは, 高血圧発症者 3,540 名の爪中水銀 濃度は 5 分位の最高位集団で毛髪水銀換算值 $2.0 \mu \mathrm{g} / \mathrm{g}$ 以 上に相当したが，交絡因子調整後の高血圧症に対する最 高位集団のハザード比は $0.94 （ 95 \% \mathrm{CI} ， 0.84 \sim 1.06 ）$ と 報告した（79）。また，魚や長鎖 $n-3$ PUFA，七レンの摂 
取量, BMI，年齢を層別化しても結果は変わらず，水銀 曝露の増加による高血圧のリスク上昇は認められなかっ た。ガーナ Upper East 州の小規模金採掘周辺の Kejetia 住民（鉱山作業員と家族）と自耕自給農業を営むGorogo 住民を検討した横断研究では, 採掘作業員の尿中および 毛髪総水銀濃度（各中央值 $5.15 \mu \mathrm{g} / \mathrm{L}, 0.946 \mu \mathrm{g} / \mathrm{g}$ ) は家 族より高かったが，Kejitia 拈よび Gorogo 住民の高血圧 有病率は各々 $17.7 \%$ と $21.3 \%$ であり, 年齢や喫煙状況 を調整した尿中扣よび毛髪水銀濃度と収縮期 / 拡張期血 圧との関連性は両住民とも有意でなかった（80)。

メチル水銀と心血管系疾患との関係については一貫性 のある結果が得られていない。これは典型的な曝露が PUFAのよらな心血管保護作用のある因子と関連する魚 掑食によってもたらされることが一因と考光られる。 チル水銀は蛋白質のスルフヒドリル基を不活化する酸化 促進剂であるため, この生化学的作用が動脈硬化防止の 際に働く重要な抗酸化防御機構を弱化させると Ginsberg らは推測した。この防御機構の1つは paraoxonase-1 (PON1）であり，この酵素は有機りン化合物の解毒に重 要であるだけでなく, 血中脂質の酸化と血管内皮沈着を 抑制する。魚多食集団ではメチル水銀が血清 PON1 活性 の低下と関連し,メチル水銀量 $0.3 \mu \mathrm{g} / \mathrm{kg} /$ 日の集団で平 均 PON1 レベルを $6.1 \%$ 減少させ，急性心血管疾患発症 リスクを $9.7 \%$ 上昇させると推計された（81）。動脈硬化 進展を抑えるPON1 は遺伝形質に依存するほか, 環境化 学物質がその活性を修飾するといら証拠も出されつつあ る。Lairdらは, 健康なイヌイット 2,172名から採取し た血中の PON1 活性と水銀, カドミウム, 鉛, セレンな どの濃度を測定し，HDL コレステロール，PUFA 濃度， 年齢, 性別, BMI, 喫煙, 飲酒量等を調整した重回帰分 析を抏こなった（82）。PON1 活性は血中セレン濃度と正 の関連があったが, 血中カドミウム濃度とは負の関連を 示し，また血中水銀や鉛濃度との有意な関連はなかった。 イヌイットの伝統食はセレン摂取量が多いことで PON1 活性を高め, 健康に供した可能性が示唆された。

\section{3 その他の影響}

メチル水銀の腎機能, 肥満, 出生サイズとの関連性も 報告されている。中国貴州省の万山水銀鉱山に拈いては, 周辺 7 地域中, 採鉱廃棄地域から $3 \mathrm{~km}$ 以内に住む 3 地 区住民の尿中水銀濃度と血清クレアチンとの間に有意な 相関が認められたが，血清尿素窒素との間に関連は見ら れなかった。これら住民の水銀摂取は, 日々の経路別摂 取量の計算より, 水銀蒸気由来でなく玄米, 野菜などか らの無機水銀由来と推定された (83)。一方 Rothenberg らは, 動物実験では肥満が血中および組織中の高い水 銀濃度と関連することは知られているが疫学研究でそ のよらな証拠は見当たらないことから，米国 NHANES （2007-2010 年）の成人と小児（2-19歳）で血液採取前 24 時間以内に魚介類を食べた参加者の二次データを用 い，血中水銀レベルが肥満に影響するか検討した。正常
体重者と比べ，肥満成人の血中水銀濃度は平均 $22 \%$ 低 かったが，肥満小児では血中水銀濃度に有意差は見られ なかった。魚介類摂取由来のメチル水銀曝露や年齢, 人 種，飲酒・喫煙歴などの交絡因子を調整すると，肥満成 人ではメチル水銀の代謝や排出が増大する可能性が示さ れた (84)。

\section{5.メチル水銀毒性を修飾する因子}

米国では，胎児の神経発達に及ぼすメチル水銀影響を 考慮して，妊娠女性の魚介類の摂取量を週に $340 \mathrm{~g}$ 以下 にすることを推奨している。しかし，魚介類には必須栄 養素の PUFA やセレン等も豊富であることから，リスク 評価の際にはそれらの影響や交互作用を検討する必要が ある。また，遺伝的な感受性の違いが水銀毒性を修飾し 得ると報告された。

\section{1 多価不飽和脂肪酸 (PUFA)}

日本の母子 367 組では, 妊娠期間に比べて小さい (small for gestational age, SGA) 新生児の発生頻度は 4.9\% であ り, 血中⿰よび毛髮水銀濃度と出生体重, 児身長, 胸囲, 頭囲との間に有意な関連はなかったが，妊娠中および分 娩時の母体血中 PUFA 值を調整すると体重の SGA リス クは毛髪水銀レベルの増加に伴い減少する関係が観察さ れた（85）。Miyashitaらは，以上ょり，魚介類に由来す る PUFA やその他必須栄養素の影響を考慮しないと, 出 生体格に及ぼすメチル水銀影響は攪乱される可能性があ ると述べた。一方, Wells らは Maryland 州 Baltimore 市 で $2004 〜 2005$ 年に生まれた単胎 271 児を対象とし, 臍 帯血中の各種水銀と血清中七レン, PUFA 值を測定した。 調整変数を在胎週数, 出生時体重, 母の年齢, 第一子か 否か, 妊娠前 BMI, 契煙歴, 高血圧症, 糖尿病, 血中 セレン, PUFA および無機水銀とした重回帰分析の結果, 臍帯血中メチル水銀濃度の高い新生児では体格指数 (ponderal index) が低下し，またメチル水銀と PUFA 間 に交互作用があり，メチル水銀と PUFA が高值の新生児 では, 出生時身長拈よび頭囲長が小さくなる傾向が示唆 された $(86)$ 。

魚由来のPUFA を摂取することで心血管疾患の予防効 果が期待できる一方, 魚に含まれるジベンゾ- $p$ - ダイオ キシンやジベンゾフラン (PCDD/Fs), PCB, メチル水 銀なぞは逆に心血管疾患リスクを高める。そこで，フィ ンランド在住の男女 1,173 人 (Health 2000 調査の参加者, 45 ～ 74 歳） と魚を多食する漁師の男女 225 人の魚摂取 量, 血清 PUFA (総脂肪酸中の相対值), 血清 PCDD/Fs $+\mathrm{PCB}$ および血中メチル水銀濃度が調べられた (87)。 全対象者で PUFA 摂取量の増加に伴い，中性脂肪が有意 に減少する傾向があり, Health2000 参加男女で腫瘍壊死 因子（TNF） $\alpha$ とインターロイキン 6 が，また同女性で インシュリン抵抗性と C 反応性タンパクが有意に減少 する傾向が認められた。これに対し, PUFA 摂取量の増 
加により，血管の硬さ（stiffness）は Health2000 参加男 性で減少し, 逆に男性漁師で増加した。男性漁師では, 血中メチル水銀濃度が高いほど血管の硬さが増し, 内頸 動脈プラーク発症率は減少する傾向が見られ, メチル水 銀などの環境污染物質の曝露影響は PUFA の摂取効果に より打ち消される可能性があると Turunen らは述べた。

\section{2 セレン}

近年, メチル水銀毒性拮抗作用を有するセレン化学形 態についての分析が進み, Yamashita らは魚の血中の主 な有機セレン化合物が抗酸化物質のセレノネインである ことを発見した (88)。これはマグロ血合肉から抽出し た有機セレン化合物を高分解能質量分析と NMR 解析で 構造分析して見出したもので, エルゴチオネインのチオ ケトン基がセレノケトン基に置換した新規化合物であっ た。同グループは，ゼブラフィッシュ胚を用いて実験を 行い, セレノネインがメチル水銀の脱メチル化を促進し, 酸化ストレス条件下でもラジカル生成を抑制すると報告 した (89)。さらに, 鹿児島県の離島住民 167 人の調査で, 赤血球中七レノネインとセレン濃度が魚摂取頻度や赤血 球中メチル水銀濃度と相関することを示し，七レノネイ ンがメチル水銀の毒性低減に貢献しているのではないか と推測した (90)。また, Zayas らはカマイルカの肝組織 中のメチル水銀全体の $60 \%$ が高分子蛋白質の水溶性分 画に存在することを見出し, メチル水銀の主な結合部位 は $\mathrm{Hb} \beta$ 鎖上のシステイン残基であり, 七レン化学形態 の大部分を占めるセレノネインが水銀毒性の軽減に関与 すると考察した (91)。

セレンの水銀毒性への作用機序を検討するため, in vitro 系に打ける亜セレン酸添加実験が繰り返し扣こな われている。ヒト肝癌由来細胞株である HepG2 細胞に 2 価の無機水銀を添加すると, 抗酸化酵素である thioredoxin-1（Trx1）の発現が高まり，亜セレン酸の同 時投与でさらに Trx1 発現が高まったが, メチル水銀と 覀セレン酸の同時投与では逆に発現が低下した（92）。 水銀毒性修飾の機序に thioredoxin 系, 寸なわちミトコ ンドリア内酸化還元酵素・抗酸化蛋白質が関与すること が示唆された。一方, 硫酸還元菌の培地に硫化物, 亜セ レン酸, 水銀イオンを添加した実験では, 細胞内セレン の蓄積量が最大でも添加セレン量の $49 \%$ にとどまり, 培養上清中にセレンが増加していたことから，水銀毒性 防御メカニズムの 1 つとして揮発性の高い亜セレン酸ジ メチルの形成が考兄らると Truong らは述べた（93）。 また，2 価水銀イオンと亜セレン酸を同時添加して培養 した場合には，無機水銀のメチル化に必要なタンパク質グルタミン酸-O-メチル転移酵素 (Dde 1198) が完全に 抑制され，細胞膜にはX 線吸収分光分析で不活性型の セレン化水銀 $(\mathrm{HgSe})$ 体が確認された（94）。

in vivo 系の実験研究では水生生物へセレンとメチル水 銀を同時経口投与した報告が多い。Penglase らはゼブラ フィッシュ雌にセレノメチオニンとメチル水銀を各々低
投与量 $(\mathrm{Se}, 0.7 ; \mathrm{Hg}, 0.05 \mathrm{mg} / \mathrm{kg})$ および高投与量（Se, $10 ; \mathrm{Hg}, 12 \mathrm{mg} / \mathrm{kg}$ ) で混飭投与する実験を行い，投与後 に各実験群の雌魚に無処置の雄を交配し, 卵と魚の水銀, セレン濃度を分析した (95)。その結果，高投与量セレ ン群で成魚と卵の水銀濃度がともに低下し，高投与量水 銀群では雌魚の生存と成長が阻害されて生殖毒性影響が 見られたが，セレンを高投与量で同時投与するとその影 響は軽減された。ゼブラフィッシュ成魚を用いた別の混 餌投与実験では (96)，セレン添加群ではメチル水銀の 肝や脳への蓄積量が低減し, 単独投与群に比べ同時投与 群で筋肉中メチル水銀濃度は明らかに低下した。一方 Mailman らは，湖のメソコスム装置（水域の一部をシー トで仕切った隔離水界）に亜セレン酸を濃度 $1.6 \mu \mathrm{g} / \mathrm{L}$ と なるよう加えた上で，安定同位体 ${ }^{198} \mathrm{Hg}$ を用いた水銀ス パイク試験を抢こなった（97）。セレンの添加は，魚 (yellow perch) 筋肉組織中のスパイク水銀濃度や肝臟中 総水銀濃度抢よびプランクトンのメチル水銀濃度を低下 させ，魚の生殖腺中七レン濃度を上昇させた。シロチョ ウザメにセレノメチオニンとメチル水銀を経口投与した 実験では，血中セレノシステイン/セレノメチオニン比 とセレン代謝産物が同時投与 48 時間後まで緩やかに増 加し, 一方肝臓ではセレン単独投与時に比べセレノメチ オニン濃度が $1 / 8$ まで低下した (98)。肝臓で生理活性の 高いセレン形態への de novo 合成が観察されるため, メ チル水銀の脱メチル化にセレンが利用されたと推測され た。国内では，高濃度の水銀を蓄積する歯クジラ類 4 種 (各種 29〜31 匹）の背部筋肉組織が分析され，セレン/ 無機水銀モル比は無機水銀レベルが高くなるにつれて低 下し，最終的にはどの種でもほぼ 1 になり，また，メチ 儿水銀が一定濃度 $(3 \sim 8 \mathrm{ppm})$ を超えると無機化が進み, $\mathrm{HgSe}$ となることが X 線吸収微細構造分析結果で示され た (99)。その他, 雌マウスの飲水にメチル水銀 $0.01 \mathrm{mM}$ を添加した実験では，リンパ組織の増殖と NK 細胞機能 が抑制され，その際セレンを混䭒すると，活性酸素種 （ROS）の産生や抗酸化作用のある酵素・物質濃度の低 下が抑えられた (100)。セレンが複数の抗酸化物質の活 性を維持したり高めたりすることで，メチル水銀の免疫 細胞毒性を緩和すると考兄られた。

セレンと水銀に関するヒト研究は少ないが，2003～ 2006 年にかけて実施された米国の NHANES 大規模疫学 研究の一環として, Park らは40歳以上 2,201 名の血・ 尿中水銀濃度と 2,117 名の血清七レン濃度を分析すると ともに，食事調査（24 時間思出し法）によりPUFA の 平均摂取量を算出した (101)。高血圧を有する対象者は $32.2 \%$ であり，年齢，性，人種，学歴，BMI，飲酒習慣， 血中コチニン濃度を調整した高血圧のオッズ比は，血中 水銀濃度が 2 倍になると $0.94(95 \% \mathrm{CI}, 0.87 \sim 1.01)$, 尿中水銀が 2 倍になると 0.87 (同, $0.78 \sim 0.99$ ） となり, セレンやPUFA の調整の有無に拘わらず，尿中水銀濃度 と高血圧罹患には負の関係があることが示された。また, 魚へのメチル水銀投与で膵ランゲルハンス島 $\beta$ 細胞が障 
害されるといら報告があることから, He らは糖尿病発 症リスクに関する前向きコホート調査を実施した (102)。20〜32 歳の 3,875 名の米国人を 18 年間追跡し, 288 名に糖尿病が発症した。特性や生活習慣, 糖尿病家 族歴, PUFA 抏よびマグネシウム摂取量等を調整すると, 爪中の水銀と七レン濃度は糖尿発症率と正に相関した。 爪中水銀濃度より 4 群に分けて比較すると, 最高位群の 最低位群に対する糖尿病発症のハザード比は 1.65 (同, 1.07 2.56）であり, 元々水銀曝露の高かった者ではイ ンスリン分泌指数（ $\beta$ 細胞機能の恒常性評価）が低下寸 ることが示された。

\section{3 アポリポタンパク遺伝子}

アポリポタンパク E (ApoE) の $\varepsilon 4$ 対立遺伝子は神経 修復力が弱いことと関連し，アルッハイマー病の危険因 子とも言われている。 $\mathrm{Ng}$ らはApoEの遺伝子多型を調べ, それが子ぞもの水銀毒性影響の修飾因子となるか否か検 討した。すなわち，2 歳児 168 名で実施した Comprehensive Developmental Inventory for Infants and Toddlers （CDIIT）と臍帯血水銀濃度との関連を調べると, ApoE が 84 対立遺伝子の場合, 認知, 言語, 微細運動 (fine motor）と負の関連を示した（103）。また， 2 歳児 166 名 の臍帯血水銀と子どもの行動チェックリスト（Child Behavior Checklist, CBCL) の関係を検討すると, 84 対立 遺伝子の場合に CBCL 得点が高く行動上の問題が多く 見られた（104）。特に内向尺度, 情緒反応や不安抑らつ 尺度との関連が認められた。以上より, 胎児期の水銀曝 露影響を評価する際, 遺伝的な感受性の違いを考慮する ことが必要であると指摘した。

\section{6. 考察}

2013 年の 10 月に熊本県水俣市で開かれた UNEP 外交 会議に打いて「水銀に関する水俣条約」が採択され（6, 7), 2016 年 2 月に日本も本条約の 23 番目の批准国となっ た。この条約の第一段階は自国の環境やヒトへのメチル 水銀 / 水銀曝露レベルを把握することであり, この曝露 評価を执こなった後に自国に合った削減方法を定めてい くことになる。このよらに，世界的にも水銀による環境 污染や健康被害防止に関心が高まっているので, メチル 水銀や水銀に関する論文数は増加し続けると考兄られ る。したがって, メチル水銀の曝露評価に関して新しい 知見を継続的に集積し, 適切に整理していくことが重要 と考えられる。但し，得られた結果が当該集団にしか当 て嵌まらない（=一般化できない）論文も中にはある。

本稿は最近のメチル水銀/水銀に関する重要な論文を 概観したが，魚介類摂取とメチル水銀曝露の利害相反が 依然としてトピックスとなっている $(62,85)$ 。魚の水銀 濃度が JECFA の規制值以下でも，妊娠可能年齢の女性 や子どもではメチル水銀曝露リスクが魚摂取による健康 有益性を上回る場合もあるので, 魚介類摂取量の推奨や
指導は, 地域 / 人種を考慮して抏こなわれるべきである。 例えば，アジア系米国人の妊娠可能年齢女性では，魚の 多食によりその胎児もリスクを背負らため, 高リスク群 のスクリーニングと指導が必須となる (46)。また，開 発途上国の鉱山周辺での環境污染は, 土䁃や水生生態系 への悪影響に加え, 魚や米を介して地域住民に健康被害 を引き起こす怖れがあることから，健康管理や保健指導 などの早急な対策が求められる。実際，水田土壌中のメ チル水銀濃度が $0.0091 \mathrm{mg} / \mathrm{kg}$ 以上では米の総水銀濃度 も許容限度を超え, ヒトに健康リスクを与えると警戒し ている (45)。その上, メチル水銀曝露のリスク評価モ デルは魚摂取をベースに想定されて扣り，米を主食とす る鉱山採掘地域住民にその毒物動態モデルをあてはめる と, 毛髪水銀濃度は低く見積もられてしまら。つまり, 環境中水銀濃度の高い地域では, 従来のリスク評価モデ ルとは別の考方方を取り入れる必要があろら。さらに, 推定 1 日水銀摂取量と HQ を用いて健康リスクを評価す るようになってきたが, メチル水銀污染魚の掑食と水銀 蒸気曝露の両方が HQ を高めるリスク要因となるので (51), 今後も監視を続け, 曝露データを積み上げていく ことが求められる。事実, yellowfin tuna の水銀濃度は毎 年 $3.8 \%$ の割合で高くなっていると推定されている (105)。 な拝，わが国でも有機水銀系農薬を使用していた頃は 米から水銀が検出されたが，この農薬が使用中止された 1973 年以降は低下し (106)，わが国の玄米に含まれる 水銀量は検出限界 $(0.03 \mathrm{ng} / \mathrm{mL})$ 以下と報告されている $(107,108)$ 。

近年のメチル水銀のヒトへの有害性に関する報告は, 主に小児の神経発達に焦点をあてた研究が目立つ。胎児 期の母体血を介したメチル水銀曝露が神経発達に影響す ることは認められたが, 出生後のメチル水銀曝露も看 過できない $(60,65)$ 。さらに低濃度曝露の場合には, 曝露指標としてメチル水銀の他, 鉛 (109), 七素 (11), $\mathrm{PCB}(15)$ などの毒性物質も考慮して神経発達段階に即 した影響評価を行い, どの曝露物質が神経発達に影響し たのかを明らかにする必要がある。特に，先進諸国では 環境レベルが著しく低下している現状を鑑み, メチル水 銀/水銀の単独曝露モデルでは特異的な神経発達影響を 十分に説明できなくなっている。すなわち，他の有害化 学物質を含む同時曝露モデルで検討することが推奨さ れ，PUFA やセレンなどの毒性修飾作用物質の測定も不 可欠である。可能性のある化学物質を全て測定する，な いし各々の測定時点で生体試料の一部を保存しておくこ

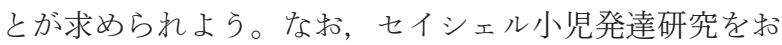
こなった Myers らは, 出産時の母親毛髪水銀濃度とと もに母体血清 PUFA（DHA やアラキドン酸など）濃度 を測定したセイシェル小児発達栄養研究の成果 (9) を 2008 年に発表した後にも, 出産時母親毛髪水銀濃度の みを用いた追跡調查を続け，低濃度の胎児期メチル水銀 曝露では神経発達影響のないことを主張し続けている $(67,69,70,110)$ 。これは魚を多食しているセイシェル国 
Table 2 WISC-III (IQ) scores after adjusting for possible covariates in predisaster and postdisaster groups: results of analysis of covariance

\begin{tabular}{|c|c|c|c|c|c|c|c|}
\hline \multirow{3}{*}{$\begin{array}{l}\text { Wechsler Intelligence } \\
\text { Scale for Children-Third } \\
\text { Edition (WISC-III) }\end{array}$} & \multirow{3}{*}{$\begin{array}{l}\text { Predisaster } \\
\text { group } \\
(\mathrm{N}=123) \\
\text { Mean } \pm \mathrm{SD}\end{array}$} & \multirow{3}{*}{$\begin{array}{l}\text { Postdisaster } \\
\text { group } \\
(\mathrm{N}=289) \\
\text { Mean } \pm \mathrm{SD}\end{array}$} & \multirow{3}{*}{$P$ value } & \multicolumn{4}{|c|}{ Covariates } \\
\hline & & & & \multirow{2}{*}{$\begin{array}{l}\text { Mental } \\
\text { processing } \\
\text { score } \\
t \text { value }\end{array}$} & \multirow{2}{*}{$\begin{array}{l}\text { Achievement } \\
\text { processing } \\
\text { score } \\
t \text { value }\end{array}$} & \multirow{2}{*}{$\begin{array}{l}\text { Tester } 1 \\
t \text { value }\end{array}$} & \multirow{2}{*}{$\begin{array}{l}\text { Tester } 2 \\
t \text { value }\end{array}$} \\
\hline & & & & & & & \\
\hline Verbal IQ & $103.9 \pm 12.2$ & $99.8 \pm 9.5$ & 0.001 & $3.84 * *$ & $8.70 * *$ & $2.90 * *$ & 0.00 \\
\hline Information & $10.5 \pm 2.9$ & $9.5 \pm 2.5$ & 0.002 & $2.28 *$ & $7.35^{* *}$ & 1.15 & -0.86 \\
\hline Similarities & $10.6 \pm 2.9$ & $10.2 \pm 2.6$ & 0.217 & 1.86 & $5.74 * *$ & 1.90 & 0.91 \\
\hline Arithmetic & $11.2 \pm 2.5$ & $10.2 \pm 2.4$ & 0.001 & $3.19^{* *}$ & $4.30 * *$ & 1.69 & 0.17 \\
\hline Vocabulary & $10.9 \pm 2.7$ & $10.1 \pm 2.3$ & 0.012 & $3.25 * *$ & $5.51 * *$ & $3.81 * *$ & 0.79 \\
\hline Comprehension & $10.0 \pm 2.9$ & $9.9 \pm 2.5$ & 0.666 & 1.61 & $4.93 * *$ & 0.86 & -1.02 \\
\hline Digit span & $9.6 \pm 1.8$ & $9.0 \pm 2.2$ & 0.010 & $5.23 * *$ & $2.06^{*}$ & 1.65 & $3.30 * *$ \\
\hline Performance IQ & $101.1 \pm 11.2$ & $101.4 \pm 10.6$ & 0.814 & $6.22 * *$ & 1.00 & 0.26 & -1.72 \\
\hline Picture completion & $10.8 \pm 2.8$ & $11.1 \pm 2.2$ & 0.349 & $3.25 * *$ & 0.93 & -0.47 & $-5.30 * *$ \\
\hline Coding & $9.1 \pm 2.4$ & $9.5 \pm 2.3$ & 0.225 & $4.15^{* *}$ & -0.69 & 1.14 & -0.89 \\
\hline Picture arrangement & $10.8 \pm 2.6$ & $10.3 \pm 2.6$ & 0.070 & $4.23 * *$ & 0.52 & -0.07 & $-2.17^{*}$ \\
\hline Block design & $9.9 \pm 2.4$ & $10.1 \pm 2.6$ & 0.686 & $4.21 * *$ & 1.43 & -0.06 & 0.50 \\
\hline Object assembly & $10.0 \pm 3.2$ & $10.1 \pm 2.8$ & 0.954 & $3.15^{* *}$ & 0.75 & 0.33 & $2.02 *$ \\
\hline Symbol search & $10.5 \pm 2.4$ & $10.3 \pm 2.3$ & 0.458 & $3.66^{* *}$ & 1.78 & $3.80 * *$ & $2.38^{*}$ \\
\hline Total IQ & $102.8 \pm 10.6$ & $100.6 \pm 9.2$ & 0.053 & $5.99 * *$ & $6.11 * *$ & 2.02 & -1.01 \\
\hline
\end{tabular}

* $P<0.05, * * P<0.001$.

$\dagger$ Covariates are Kaufman Assessment Battery for Children (K-ABC) scores (i.e., mental and achievement processing scores after adjusting for maternal drinking habit during pregnancy and testers of $\mathrm{K}-\mathrm{ABC}$ ) and testers of WISC-III. Data of these covariates were newly added in Table III of Ref\#117.

民向けのメッセージ以上のものではないと解釈すべきで あろら。

フェロー出生コホート研究グループは胎児期メチル水 銀曝露による高次神経影響が 22 歳になったコホートで 観察されたと報告した（111）。胎児性水俣病や森永七素 ミルク事件の報告では神経中毒症状が非可逆的と考光ら れる症例が多数あり $(1,3,11,112)$, このよらな神経発 達影響を時系列的に捉えることが重要である。そのヒン トは2 011 年に発生した東日本大震災前後の 7 歳児の IQ 結果にある (Table 2)。IQ は生まれつきの能力であり, 両親の遺伝形質, すなわち親の IQ が交絡すると考光ら れているが (113), 人為的に考案された IQ 検査法は素 質を評価するものもあれば，生後の教育・生活環境を反 映した能力を表すものもあり，それらを一緾めにして IQ と称している。例えば, Kaufman 心理・教育ア七ス メントバッテリー（K-ABC）は認知処理過程尺度と習 得度尺度に大別され (114), 前者は学業等に影響されな い生まれつきの能力, 後者は文化・教育環境によって変 わりらる能力と考兄られている(115)。また, Wechsler 知能検査 (WISC-III) には言語性 IQ と動作性 IQ の 2 種 類がある (116)。Tatsutaらはこれまであまり明らかでな かった WISC-III の IQ と K-ABC 検査得点との関係を検 討し (117), 動作性 IQ は認知処理過程尺度と関連するが, 言語性 IQ は認知処理過程尺度だけでなく習得度尺度と も関連することを示した。したがって，今後の知能検査 を用いる研究では, 神経毒性物質（例えば，メチル水銀，
鉛，七素など）がどのような IQ に影響するのか (118), IQ 低下は胎児期曝露と生後曝露のどちらによってもた らされるのかを明確にする必要があろら。尤必，注意欠 如 / 多動性障害や自閉症の患者では IQ 検査細目の選択 的障害が観察されて招り $(119,120)$, IQ 検査の再定義 / 再編も必要となるか子しれない。

20 世紀後半に妊婦の魚介類由来のメチル水銀曝露と 出生体重の関係が議論されたが $(121,122)$ ，その結論は 相反するものであった。2015 年に同様の関係を検討し た報告は 3 編あった。Obi らの報告では $1.2 \sim 10.6$ (平 均 5.1) $\mu \mathrm{g} / \mathrm{L}$ の臍帯血水銀濃度が出生体重（平均 $3.4 \mathrm{~kg}$ ) と有意な正の関連を示した (58)。Miyashita らは, PUFA 等を調整すると, 母親毛髪水銀濃度の増加に伴い平均出 生体重 3,073g の集団の SGA リスクが減少すると報告し た (85)。一方, Wells らは, 臍帯血のメチル水銀拈よび PUFA が高いと, 出生時 (平均体重 3,212 g) の身長と頭 囲長が短くなる可能性を示唆した（86）。すなわち，交 絡因子に何を使用したかによって出生時体格に及ぼすメ チル水銀影響が変わり，一定の結論に到達していない。 このようなことは測定した有害化学物質の曝露濃度が低 くかつその曝露レンジが小さい場合に起こり易い。した がって, 出生時体格の異常頻度に関わる因子の個々の寄 与率を重回帰分析の重相関係数 $R^{2}$ の差分から計算し, 有意であってもその寄与率が極端に小さいか“ありそら にない”場合は「考察」の中で正当化しない（=コメン トするに值しないと考光る）ことも選択肢の一つとなる 
（123）。少なくとも, SGA 児や低体重出生児の研究に抒 いて妊娠中の詳細な喫煙情報（妊娠期間中の総喫煙本数, 受動喫煙の程度と頻度など）を欠くならば (124), 本質 から乘離した議論となろら。

神経発達に及ぼす有害化学物質の影響には性差があ り, 6 ヶ月男児の MDI 得点 (BSID-II) が毛髪水銀濃度と, また 6 ヶ月女児の MDI 得点が有機フッ素化合物のパー フルオロオクタン酸（PFOA） と各々負に関連すること が報告された $(66,75)$ 。また男児の $\mathrm{K}-\mathrm{ABC}$ 得点は女児 よりも低下し，かつ臍帯血中 PCB の 9 塩素体 (9CB) と関連することも示された（15）。このように性差を意 識して解析することは新たな発見に結びつくが, 研究デ ザインの段階で性差を検出できるサンプルサイズを確保 しているかどらかが鍵となる。

低濃度メチル水銀曝露がヒトの心血管系に悪影響を及 ぼすか否かについては (25-27), 傍証は存在するものの $(59,68,81,82,125)$, 未だ決着がついていない。低濃度 メチル水銀（あるいは無機水銀）懪露による小規模鉱山 周辺住民の心血管系への影響評価に関する研究では, 高 血圧の有病率は鉱山従業員括よび家族と対照地域住民と の間で差異はなく，しかも尿中执よび毛髪中水銀濃度と 収縮期および拡張期血圧との間に性, 年齢, 哭煙状況を 調整しても有意な相関は認められなかった $(80)$ 。胎児 期と生後のメチル水銀曝露で心血管系影響が同じか否か については, 特に PUFA やセレン濃度を考慮しつつ検討 しなくてはならない $(81,82) 。$

水銀毒性を生体内で修飾する微量栄養素として，七レ ン等の役割や機序が調べられている(126-129)。ヒトに 抢いてセレンがメチル水銀の神経毒性に直接的な拮抗作 用を示す証拠は未だないものの (130), これまでの動物 実験でセレンがメチル水銀の毒性を減弱させることは実 証されて打り $(89,131)$, ヒト胎児期のメチル水銀曝露 影響を考える上で, セレンの潜在的重要性を軽視するこ とはできない。生体内組織でのセレンと水銀の複合体形 成に関する解析が進んで抢り, 海棲哺乳動物組織内の総 水銀濃度が高くなるにつれて無毒化された HgSe が出現 することが示され，七レンが水銀毒性の軽減に一役買っ ていることが裏づけられた $(17,99)$ 。臍帯血のメチル水 銀濃度は母体血の 2 倍程度高いにもかかわらず母子間の 七レン濃度に差がないことから（132）, 今後水銀とセレ ン濃度との関連性が見られなかった胎児などでの検討が 必要となる。セレンと水銀の相互作用を他の物質との相 互作用から切り離して評価するのは困難であり, 栄養素 のPUFA や環境污染物質の PCB 等の修飾影響について も, 併せて研究が推進されることを期待したい。なお, PUFA の濃度表示には絶対值が使用されるべきであり, 血清脂肪酸值に対する相対值（\%) を用いると得られた 結果の解釈に混乱を生じ易い $(62,87)$ 。

最後に, 小規模金採掘場で金抽出に水銀一金アマルガ ム法を使用すると, 周辺の土壌のみならず動植物に対し ても水銀污染が発生する(133)。しか子金採掘周辺の河
川や河口堆積物にまで水銀污染は及び，さらに農業・漁 業資源を経由することで地域住民への健康被害が懸念さ れる (41-44)。水銀一金アマルガム法と異なる金抽出法 としてシアン化法もあるが，これも河川にシアン化合物 を大量に放出することになり，水生微小動物の減少など の生物多様性に悪影響を与える(134)。このように金抽 出に水銀一金アマルガム法やシアン化法を用いることは いずれも環境污染や地域住民に健康被害を惹起する可能 性が高い。近年，この金抽出に水銀やシアンを用いない 嗍砂による新たな抽出技術が開発され $(135,136)$, 今後 の水銀污染防止策に期待が寄せられる。

\section{7. 結語}

水俣会議での水銀条約の採択以後, 各国でメチル水銀 の曝露評価に関心が高まって打り, メチル水銀/水銀に 関する論文総数は増加している。疫学研究で依然として 注目されているのはメチル水銀の神経毒性に最も感受性 の高い胎児期の曝露影響である。これは環境污染に由来 する低濃度曝露による小児発達影響といら環境保健学的 にも究明すべき最重要課題の一つであるが，軽度でかつ 特異性も乏しい影響をより精確に把握する必要があり, この困難を克服する方策を新たに開発していかねばなら ない。また, 出生コホートが成長する中で IQ 低下や機 能低下が持続するのか, 生後の低濃度メチル水銀曝露に よって悪影響がもたらされるのか, 今後の課題は尽きな い。さらに，検出しょうとする影響を攪乱する $\mathrm{PCB} や$ 殺虫剂系毒性物質など，低濃度での同時曝露による影響 の評価も益々重視される。このために検査法や相互作用 の見直しを踏まえた研究デザインの立案が求められる。 メチル水銀毒性の修飾作用機序については未だ不明な点 も多く, ヒトでのデータの蓄積が重要であることは言ら までもないが，さらに実験的执よび分子毒性学的研究を 組み合わせた双方向のアプローチによって毒性機序の解 明が一層進展することに期待したい。

\section{謝辞}

本研究は環境省受託研究「重金属等の健康影響に関す る総合研究 (平成 $25,26,27$ 年度)」の研究費補助（日 本エヌ・ユー・エス株式会社）を受けた。

本研究に係る利益相反はない。

\section{文献}

（1）西村 肇, 岡本達明. 水俣病の科学 (増補版). 東京: 日本評論社, 2006.

( 2 ) Grandjean P, Satoh H, Murata K, Eto K. Adverse effects of methylmercury: environmental health research implications. Environ Health Perspect 2010;118:1137-1145. 
( 3 ) Murata K, Sakamoto M. Minamata disease. In: Nriagu JO (ed). Encyclopedia of Environmental Health, Volume 3. Burlington: Elsevier, 2011;774-780.

（４）村田勝敬, 吉田 稔, 坂本峰至, 岩井美幸, 柳沼 梢, 龍田 希, 岩田豊人, 苅田香苗, 仲井邦彦. メチル 水銀毒性に関する疫学的研究の動向. 日本衛生学雑 誌 2011;66:682-695.

( 5 ) Satoh H. Mercury. In: Weiss B (ed). Aging and Vulnerability to Environmental Chemicals: Age-related Disorders and their Origins in Environmental Exposures. Cambridge: RSC Publishing, 2013;125-149.

( 6 ) http://www.unep.org/PDF/PressReleases/GlobalMercury Assessment2013.pdf\#search='UNEP+mercury (2016.6.7)

( 7 ) http://www.unep.org/chemicalsandwaste/Portals/9/Mercury/ Documents/Publications/Mercury\%20Acting\%20Now.pdf (2016.6.7)

（８）村田勝敬. 意味の異なる 2 つの “予防”. 日本衛生学 雑誌 2008;63:662.

( 9 ) Strain JJ, Davidson PW, Bonham MP, Duffy EM, StokesRiner A, Thurston SW, Wallace JM, Robson PJ, Shamlaye CF, Georger LA, Sloane-Reeves J, Cernichiari E, Canfield RL, Cox C, Huang LS, Janciuras J, Myers GJ, Clarkson TW. Associations of maternal long-chain polyunsaturated fatty acids, methyl mercury, and infant development in the Seychelles child development nutrition study. Neurotoxicology 2008;29:776-782.

( 10 ) Canfield RL, Henderson CR Jr, Cory-Slechta DA, Cox C, Jusko TA, Lanphear BP. Intellectual impairment in children with blood lead concentrations below $10 \mu \mathrm{g}$ per deciliter. N Engl J Med 2003;348:1517-1526.

( 11 ) Dakeishi M, Murata K, Grandjean P. Long-term consequences of arsenic poisoning during infancy due to contaminated milk powder. Environ Health 2006;5:31.

(12) Surkan PJ, Zhang A, Tranchtenberg F, Daniel DB, McKinlay S, Bellinger DC. Neuropsychological function in children with blood lead levels $<10 \mu \mathrm{g} / \mathrm{dl}$. Neurotoxicology 2007;28:1170-1177.

( 13 ) Jusko TA, Henderson CR, Lanphear BP, Cory-Slechta DA, Parsons PJ, Canfield RL. Blood lead concentrations $<10 \mu \mathrm{g} / \mathrm{dl}$ and child intelligence at 6 years of age. Environ Health Perspect 2008;116:243-248.

( 14 ) Tatsuta N, Nakai K, Murata K, Suzuki K, Iwai-Shimada M, Yaginuma-Sakurai K, Kurokawa N, Nakamura T, Hosokawa T, Satoh H. Prenatal exposures to environmental chemicals and birth order as risk factor for child behavior problems. Environ Res 2012;114:47-52.

( 15 ) Tatsuta N, Nakai K, Murata K, Suzuki K, Iwai-Shimada M, Kurokawa, Hosokawa T, Satoh H. Impacts of prenatal exposures to polychlorinated biphenyls, methylmercury and lead on intellectual ability of 42-month-old children in Japan. Environ Res 2014;133:321-326.

( 16 ) Karita K, Suzuki T. Fish eating and variations in selenium and mercury levels in plasma and erythrocytes in freeliving healthy Japanese men. Biol Trace Elem Res 2002; 90:71-81.

( 17 ) Nakamura M, Hachiya N, Murata KY, Nakanishi I, Kondo T, Yasutake A, Miyamoto K, Ser PH, Omi S, Furusawa H,
Watanabe C, Usuki F, Sakamoto M. Methylmercury exposure and neurological outcomes in Taiji residents accustomed to consuming whale meat. Environ Int 2014;68:2532.

( 18 ) http://edoc.mpg.de/478647 (2016.6.7)

(19) Grandjean P, Weihe P, White RF, Debes F, Araki S, Yokoyama K, Murata K, Sørensen N, Dahl R, Jørgensen PJ. Cognitive deficit in 7-year-old children with prenatal exposure to methylmercury. Neurotoxicol Teratol 1997;19: $417-428$.

(20) Davidson PW, Myers GJ, Cox C, Axtell C, Shamlaye C, Sloane-Reeves J, Cernichiari E, Needham L, Choi A, Wang Y, Berlin M, Clarkson TW. Effects of prenatal and postnatal methylmercury exposure from fish consumption on neurodevelopment: outcomes at 66 months of age in the Seychelles child development study. JAMA 1998;280: 701-707.

(21) Murata K, Weihe P, Araki S, Budtz-Jørgensen E, Grandjean P. Evoked potentials in Faroese children prenatally exposed to methylmercury. Neurotoxicol Teratol 1999;21:471-472.

(22) Sørensen N, Murata K, Budtz-Jørgensen E, Weihe P, Grandjean P. Prenatal methylmercury exposure as a cardiovascular risk factor at seven years of age. Epidemiology 1999;10:370-375.

( 23 ) Grandjean P, Weihe P, Burse VW, Needham LL, StorrHansen E, Heinzow B, Debes F, Murata K, Simonsen H, Ellefsen P, Budtz-Jørgensen E, Keiding N, White RF. Neurobehavioral deficits associated with PCB in 7-yearold children prenatally exposed to seafood neurotoxicants. Neurotoxicol Teratol 2001;23:305-317.

( 24 ) Myers GJ, Davidson PW, Cox C, Shamlaye CF, Palumbo D, Cernichiari E, Sloane-Reeves J, Wilding GE, Kost J, Huang LS, Clarkson TW. Prenatal methylmercury exposure from ocean fish consumption in the Seychelles child development study. Lancet 2003;361:1686-1692.

( 25 ) Salonen JT, Seppanen K, Nyyssonen K, Korpela H, Kauhanen J, Kantola M, Tuomilehto J, Esterbauer HH, Tatzber F, Salonen R. Intake of mercury from fish, lipid peroxidation, and the risk of myocardial infarction and coronary, cardiovascular, and any death in eastern Finnish men. Circulation 1995;91:645-655.

( 26 ) Guallar E, Sanz-Gallardo MI, vant Veer PV, Bode P, Aro A, Gomez-Aracena J, Kark JD, Riemersma RA, MartinMoreno JM, Kok FJ. Mercury, fish oils, and the risk of myocardial infarction. N Engl J Med 2002;347:17471754.

( 27 ) Yoshizawa K, Rimm EB, Morris JS, Spate VL, Hsieh CC, Spiegelman D, Stampfer MJ, Willett WC. Mercury and the risk of coronary heart disease in men. N Engl J Med 2002;347:1755-1760.

( 28 ) Davidson PW, Strain JJ, Myers GJ, Thurston SW, Bonham MP, Shamlaye CF, Stokes-Riner A, Wallace JM, Robson PJ, Duffy EM, Georger LA, Sloane-Reeves J, Cernichiari E, Canfield RL, Cox C, Huang LS, Janciuras J, Clarkson TW. Neurodevelopmental effects of maternal nutritional status and exposure to methylmercury from eating fish 
during pregnancy. Neurotoxicology 2008;29:767-775.

( 29 ) Grandjean P. Seven deadly sins of environmental epidemiology and the virtues of precaution. Epidemiology 2008; 19:158-162.

( 30 ) Kawamoto T, Nitta H, Murata K, Toda E, Tsukamoto N, Hasegawa M, Yamagata Z, Kayama F, Kishi R, Ohya Y, Saito H, Sago H, Okuyama M, Ogata T, Yokoya S, Koresawa Y, Shibata Y, Nakayama S, Michikawa T, Takeuchi A, Satoh H, Working Group of the Epidemiological Research for Children's Environmental Health. Rationale and study design of the Japan environment and children's study (JECS). BMC Public Health 2014;14:25.

( 31 ) Landrigan PJ, Baker DB. The National Children's Studyend or new beginning? N Engl J Med 2015;372:14861489.

( 32 ) Pearson H. Wanted: 80,000 British babies for massive study: UK launches effort to track children from birth, months after US counterpart closes. Nature 2015;518:464465.

(33) Sheehan MC, Burke TA, Navas-Acien A, Breysse PN, McGready J, Fox MA. Global methylmercury exposure from seafood consumption and risk of developmental neurotoxicity: a systematic review. Bull World Health Organ 2014;92:254-269.

（34）村田勝敬, 获石美和子, 島田美幸, 佐藤 洋. メチ 儿水銀の胎児期曝露の生体指標としての臍帯水銀濃 度の有用性の検討. 日本衛生学雑誌 2007;62:949959.

( 35 ) Sakamoto M, Yasutake A, Doming JD, Chan HM, Kubota M, Murata K. Relationships between trace element concentrations in chorionic tissue of placenta and umbilical cord tissue: potential use as indicators for prenatal exposure. Environ Int 2013;60:106-111.

( 36 ) Sakamoto M, Chan HM, Domingo JL, Kubota M, Murata $\mathrm{K}$. Changes in body burden of mercury, lead, arsenic, cadmium and selenium in infants during early lactation in comparison with placental transfer. Ecotoxicol Environ Saf 2012;84:179-184.

(37) Sakamoto M, Chan HM, Domingo JL, Kawakami S, Murata K. Mercury and docosahexaenoic acid levels in maternal and cord blood in relation to segmental maternal hair mercury concentrations at parturition. Environ Int 2012;44:112-117.

(38) Sakamoto M, Chan HM, Domingo JL, Oliveira RB, Kawakami S, Murata K. Significance of fingernail and toenail mercury concentrations as biomarkers for prenatal methylmercury exposure in relation to segmental hair mercury concentrations. Environ Res 2015;136:289-294.

( 39 ) Iwai-Shimada M, Satoh H, Nakai K, Tatsuta N, Murata K, Akagi H. Methylmercury in the breast milk of Japanese mothers and lactational exposure of their infants. Chemosphere 2015;126:67-72.

(40) Iwata T, Sakamoto M, Feng X, Yoshida M, Liu XJ, Dakeishi M, Li P, Qiu G, Jiang H, Nakamura M, Murata $\mathrm{K}$. Effects of mercury vapor exposure on neuromotor function in Chinese miners and smelters. Int Arch Occup Environ Health 2007;80:381-387.
( 41 ) Meng M, Li B, Shao JJ, Wang T, He B, Shi JB, Ye ZH, Jiang GB. Accumulation of total mercury and methylmercury in rice plants collected from different mining areas in China. Environ Pollut 2013;184:179-186.

( 42 ) Qiu G, Feng X, Meng B, Zhang C, Gu C, Du B, Lin Y. Environmental geochemistry of an abandoned mercury mine in Yanwuping, Guizhou Province, China. Environ Res 2013;125:124-130.

(43) Li B, Shi JB, Wang X, Meng M, Huang L, Qi XL, He B, Ye ZH. Variations and constancy of mercury and methylmercury accumulation in rice grown at contaminated paddy field sites in three Provinces of China. Environ Pollut 2013;181:91-97.

( 44 ) Nakazawa K, Nagafuchi O, Kawakami T, Inoue T, Yokota K, Serikawa Y, Cyio B, Elvince R. Human health risk assessment of mercury vapor around artisanal small-scale gold mining area, Palu city, Central Sulawesi, Indonesia. Ecotoxicol Environ Saf 2015;124:155-162.

(45) Li P, Feng X, Chan HM, Zhang X, Du B. Human body burden and dietary methylmercury intake: the relationship in a rice-consuming population. Environ Sci Technol 2015;49:9682-9689.

(46) Xu X, Newman MC. Mercury exposure as a function of fish consumption in two Asian communities in Coastal Virginia, USA. Arch Environ Contam Toxicol 2015;68: 462-475.

( 47 ) Buchanan S, Anglen J, Turyk M. Methyl mercury exposure in populations at risk: analysis of NHANES 20112012. Environ Res 2015;140:56-64.

( 48 ) Yang HR, Kim NY, Hwang LH, Park JS, Kim JH. Mercury contamination and exposure assessment of fishery products in Korea. Food Addit Contam (Part B) 2015;8: 44-49.

( 49 ) Basu N, Tutino R, Zhang Z, Cantonwine DE, Goodrich JM, Somers EC, Rodriguez L, Schnaas L, Solano M, Mercado A, Peterson K, Sanchez BN, Hernandez-Avila M, $\mathrm{Hu} \mathrm{H}$, Tellez-Rojo MM. Mercury levels in pregnant women, children, and seafood from Mexico City. Environ Res 2014;135:53-69.

( 50 ) Lei B, Zhang K, An J, Zhang X, Yu Y. Human health risk assessment of multiple contaminants due to consumption of animal-based foods available in the markets of Shanghai, China. Environ Sci Pollut Res 2015;22:44344446.

( 51 ) Castilhos Z, Rodrigues-Filho S, Cesar R, Rodrigues AP, Villas-Bôas R, de Jesus I, Lima M, Faial K, Miranda A, Brabo E, Beinhoff C, Santos E. Human exposure and risk assessment associated with mercury contamination in artisanal gold mining areas in the Brazilian Amazon. Environ Sci Pollut Res Int 2015;22:11255-11264.

( 52 ) Bastos WR, Dórea JG, Bernardi JV, Lauthartte LC, Mussy MH, Lacerda LD, Malm O. Mercury in fish of the Madeira river (temporal and spatial assessment), Brazilian Amazon. Environ Res 2015;140:191-197.

( 53 ) Ceccatto AP, Testoni MC, Ignácio AR, Santos-Filho M, Malm O, Díez S. Mercury distribution in organs of fish species and the associated risk in traditional subsistence 
villagers of the Pantanal wetland. Environ Geochem Health 2016;38:713-722.

( 54 ) Olivero-Verbel J, Caballero-Gallardo K, Turizo-Tapia A. Mercury in the gold mining district of San Martin de Loba, South of Bolivar (Colombia). Environ Sci Pollut Res Int 2015;22:5895-5907.

( 55 ) Pinedo-Hernández J, Marrugo-Negrete J, Díez S. Speciation and bioavailability of mercury in sediments impacted by gold mining in Colombia. Chemosphere 2015;119: 1289-1295.

( 56 ) López-Blanco C, Collahuazo L, Torres S, Chinchay L, Ayala D, Benítez P. Mercury pollution in soils from the Yacuambi river (Ecuadorian Amazon) as a result of gold placer mining. Bull Environ Contam Toxicol 2015;95: 311-316.

( 57 ) Niane B, Guédron S, Moritz R, Cosio C, Ngom PM, Deverajan N, Pfeifer HR, Poté J. Human exposure to mercury in artisanal small-scale gold mining areas of Kedougou region, Senegal, as a function of occupational activity and fish consumption. Environ Sci Pollut Res Int 2015;22:7101-7111.

( 58 ) Obi E, Okafor C, Igwebe A, Ebenebe J, Afonne OJ, Ifediata F, Orisakwe OE, Nriagu JO, Basu N. Elevated prenatal methylmercury exposure in Nigeria: evidence from maternal and cord blood. Chemosphere 2015;119: 485-489.

( 59 ) Grandjean P, Murata K, Budtz-Jørgensen E, Weihe P. Cardiac autonomic activity in methylmercury neurotoxicity: 14-year follow-up of a Faroese birth. J Pediatr 2004; 144:169-176.

( 60 ) Murata K, Weihe P, Budtz-Jørgensen E, Jørgensen PJ, Grandjean P. Delayed brainstem auditory evoked potential latencies in 14-year-old children exposed to methylmercury. J Pediatr 2004;144:177-183.

( 61 ) Debes F, Budtz-Jørgesen E, Weihe P, White RF, Grandjean P. Impact of prenatal methylmercury exposure on neurobehavioral function at age 14 years. Neurotoxicol Teratol 2006;28:627-632.

(62) Choi AL, Mogensen UB, Bjerve KS, Debes F, Weihe P, Grandjean P, Budtz-Jørgensen E. Negative confounding by essential fatty acids in methylmercury neurotoxicity associations. Neurotoxicol Teratol 2014;42:85-92.

(63) Grandjean P, Weihe P, Debes F, Choi AL, Budtz-Jørgensen E. Neurotoxicity from prenatal and postnatal exposure to methylmercury. Neurotoxicol Teratol 2014;43:39-44.

( 64 ) Osuna CE, Grandjean P, Weihe P, El-Fawal HA. Autoantibodies associated with prenatal and childhood exposure to environmental chemicals in Faroese children. Toxicol Sci 2014;142:158-166.

( 65 ) Hsi HC, Jiang CB, Yang TH, Chien LC. The neurological effects of prenatal and postnatal mercury/methylmercury exposure on three-year-old children in Taiwan. Chemosphere 2014;100:71-76.

(66) Marques RC, Bernardi JVE, Abreu L, Dorea JG. Neurodevelopment outcomes in children exposed to organic mercury from multiple sources in a tin-ore mine environment in Brazil. Arch Environ Contam Toxicol 2015;68:
432-441.

(67) van Wijngaarden E, Thurston SW, Myers GJ, Strain JJ, Weiss B, Zarcone T, Watson GE, Zareba G, McSorley EM, Mulhem MS, Yeates AJ, Henderson J, Gedeon J, Shamlaye CF, Davidson PW. Prenatal methylmercury exposure in relation to neurodevelopment and behavior at 19 years of age in the Seychelles Child Development Study. Neurotoxicol Teratol 2013;39:19-25.

(68) Murata K, Sakamoto M, Nakai K, Dakeishi M, Iwata T, Liu XJ, Satoh H. Subclinical effects of prenatal methylmercury exposure on cardiac autonomic function in Japanese children. Int Arch Occup Environ Health 2006;79: 379-386.

(69) Periard D, Beqiraj B, Hayoz D, Viswanathan B, Evans K, Thurston SW, Davidson PW, Myers GJ, Bovet P. Associations of baroreflex sensitivity, heart rate variability, and initial orthostatic hypotension with prenatal and recent postnatal methylmercury exposure in the Seychelles child development study at age 19 years. Int J Environ Res Public Health 2015;12:3395-3405.

( 70 ) Strain JJ, Yeates AJ, van Wijngaarden E, Thurston SW, Mulhem MS, McSorley EM, Watson GE, Love TM, Smith TH, Yost K, Harrington D, Shamlaye CF, Henderson J, Myers GJ, Davidson PW. Prenatal exposure to methyl mercury from fish consumption and polyunsaturated fatty acids: associations with child development at $20 \mathrm{mo}$ of age in an observational study in the Republic of Seychelles. Am J Clin Nutr 2015;101:530-537.

(71) van Wijngaarden E, Davidson PW, Smith TH, Evans K, Yost K, Love T, Thurston SW, Watson GE, Zareba G, Bums CM, Shamlaye CF, Myers GJ. Autism spectrum disorder phenotypes and prenatal exposure to methylmercury. Epidemiology 2013;24:651-659.

( 72 ) Watson GE, van Wijngaarden E, Love TM, McSorley EM, Bonham MP, Mulhem MS, Yeates AJ, Davidson PW, Shamlaye CF, Strain JJ, Thurston SW, Hamington D, Zareba G, Wallace JM, Myers GJ. Neurodevelopmental outcomes at 5 years in children exposed prenatally to maternal dental amalgam: The Seychelles Child Development Nutrition Study. Neurotoxicol Teratol 2013;39:57-62.

(73) van Wijngaarden E, Harrington D, Kobrosly R, Thurston SW, O'Hara T, McSorley EM, Myers GJ, Watson GE, Shamlaye CF, Strain JJ, Davidson PW. Prenatal exposure to methylmercury and LCPUFA in relation to birth weight. Ann Epidemiol 2014;24:273-278.

( 74 ) Suzuki K, Nakai K, Sugawara T, Nakamura T, Ohba T, Shimada M, Hosokawa T, Okamura K, Sakai T, Kurokawa N, Murata K, Satoh C, Satoh H. Neurobehavioral effects of prenatal exposure to methylmercury and PCBs and seafood intake: Neonatal Behavioral Assessment Scale results of Tohoku Study of Child Development. Environ Res 2010;110:699-704.

( 75 ) Goudarzi H, Nakajima S, Ikeno T, Sasaki S, Kobayashi S, Miyashita C, Ito S, Araki A, Nakazawa H, Kishi R. Prenatal exposure to perfluorinated chemicals and neurodevelopment in early infancy: The Hokkaido Study. Sci Total Environ 2016;541:1002-1010. 
( 76 ) Orenstein STC, Thurston SW, Bellinger DC, Schwartz JD, Amarasiriwardena CJ, Altshul LM, Korrick SA. Prenatal organochlorine and methylmercury exposure and memory and learning in school-age children in communities near the New Bedford harbor superfund site, Massachusetts. Environ Health Perspect 2015;122:1253-1259.

( 77 ) Inoue S, Yorifuji T, Tsuda T, Doi H. Short-term effect of severe exposure to methylmercury on atherosclerotic heart disease and hypertension mortality in Minamata. Sci Total Environ 2012;417-418:291-293.

( 78 ) Kalish BT, Rifas-Shiman SL, Wright RO, Amarasiriwardena CJ, Jayawardene I, Jayawardene I, Gillman MW, Lipshultz ST, Oken E. Associations of prenatal maternal blood mercury concentrations with early and mid-childhood blood pressure: a prospective study. Environ Res 2014;133:327-333.

( 79 ) Mozaffarian D, Shi P, Morris JS, Grandjean P, Siscovick DS, Spieqelman D, Willett WC, Rimm EB, Curhan GC, Forman JP. Mercury exposure and risk of hypertension in US men and women in 2 prospective cohort. Hypertension 2012;60:645-652.

( 80 ) Rajaee M, Sánchez BN, Renne EP, Basu N. An investigation of organic and inorganic mercury exposure and blood pressure in a small-scale gold mining community in Ghana. Int J Environ Res Public Health 2015;12:1002010038.

(81) Ginsberg G, Sonawane B, Nath R, Lewandowski P. Methylmercury-induced inhibition of paraoxonase-1 (PON1)-implications for cardiovascular risk. J Toxicol Environ Health 2014;77:1004-1023.

( 82 ) Laird BD, Goncharov AB, Ayotte P, Chan HM. Relationship between the esterase paraoxonase-1 (PON1) and metal concentrations in the whole blood of Inuit in Canada. Chemosphere 2015;120:479-485.

( 83 ) Li P, Du B, Chan HM, Feng X. Human inorganic mercury exposure, renal effects and possible pathways in Wanshan mercury mining area, China. Environ Res 2015;140:198204.

( 84 ) Rothenberg SE, Korrick SA, Fayad R. The influence of obesity on blood mercury levels for U.S. non-pregnant adults and children: NHANES 2007-2010. Environ Res 2015;138:173-180.

( 85 ) Miyashita C, Sasaki S, Ikeno T, Araki A, Ito S, Kajiwara J, Todaka T, Hachiya N, Yasutake A, Murata K, Nakajima T, Kishi R. Effects of in utero exposure to polychlorinated biphenyls, methylmercury, and polyunsaturated fatty acids on birth size. Sci Total Environ 2015;533:256-265.

( 86 ) Wells EM, Herbstman JB, Lin YH, Jarrett J, Verdon CP, Ward C, Caldwell KL, Hibbeln JR, Witter FR, Halden RU, Goldman LR. Cord blood methylmercury and fetal growth outcomes in Baltimore newborns: potential confounding and effect modification by omega-3 fatty acids, selenium, and sex. Environ Health Perspect 2016;124:373-379.

( 87 ) Turunen AW, Jula A, Suominen AL, Männistö S, Marniemi J, Kiviranta H, Tiittanen P, Karanko H, Moilanen L, Nieminen MS, Kesäniemi YA, Kähönen M, Verkasalo PK. Fish consumption, omega-3 fatty acids, and environmental contaminants in relation to low-grade inflammation and early atherosclerosis. Environ Res 2013; 120:43-54.

( 88 ) Yamashita Y, Yamashita M. Identification of a novel selenium-containing compound, selenoneine, as the predominant chemical form of organic selenium in the blood of bluefin tuna. J Biol Chem 2010;285:18134-18138.

( 89 ) Yamashita M, Yamashita Y, Suzuki T, Kani Y, Mizusawa N, Imamura S, Takemoto K, Hara T, Hossain MA, Yabu T, Touhata K. Selenoneine, a novel selenium-containing compound, mediates detoxification mechanisms against methylmercury accumulation and toxicity in zebrafish embryo. Mar Biotechnol 2013;15:559-570.

( 90 ) Yamashita M, Yamashita Y, Ando T, Wakamiya J, Akiba S. Identification and determination of selenoneine, 2-selenyl$\mathrm{N} \alpha, \mathrm{N} \alpha, \mathrm{N} \alpha$-trimethyl-L-histidine, as the major organic selenium in blood cells in a fish-eating population on remote Japanese Islands. Biol Trace Elem Res 2013;156:3644.

(91) Zayas ZP, Ouerdane L, Mounicou S, Lobinski R, Monperrus M, Amouroux D. Hemoglobin as a major binding protein for methylmercury in white-sided dolphin liver. Anal Bioanal Chem 2014;406:1121-1129.

( 92 ) Branco V, Godinho-Santos A, Gonçalves J, Lu J, Holmgren A, Carvalho C. Mitochondrial thioredoxin reductase inhibition, selenium status, and Nrf-2 activation are determinant factors modulating the toxicity of mercury compounds. Free Radic Biol Med 2014;73:95-105.

( 93 ) Truong HY, Chen YW, Belzile N. Effect of sulfide, selenite and mercuric mercury on the growth and methylation capacity of the sulfate reducing bacterium Desulfovibrio desulfuricans. Sci Total Environ 2013;449:373-384.

( 94 ) Truong HY, Chen YW, Saleh M, Nehzati S, George GN, Pickering IJ, Belzile N. Proteomics of Desulfovibrio desulfuricans and X-ray absorption spectroscopy to investigate mercury methylation in the presence of selenium. Metallomics 2014;6:465-475.

( 95 ) Penglase S, Hamre K, Ellingsen S. Selenium and mercury have a synergistic negative effect on fish reproduction. Aquat Toxicol 2014;149:16-24.

( 96 ) Amlund H, Lundebye AK, Boyle D, Ellingsen S. Dietary selenomethionine influences the accumulation and depuration of dietary methylmercury in zebrafish (Danio rerio). Aquat Toxicol 2015;158:211-217.

( 97 ) Mailman M, Bodaly RA, Paterson MJ, Thompson S, Flett RJ. Low-level experimental selenite additions decrease mercury in aquatic food chains and fish muscle but increase selenium in fish gonads. Arch Environ Contam Toxicol 2014;66:32-40.

( 98 ) Huang SS, Hung SS, Chan HM. Maintaining tissue selenium species distribution as a potential defense mechanism against methylmercury toxicity in juvenile white sturgeon (Acipenser transmontanus). Aquat Toxicol 2014;156:8895.

( 99 ) Sakamoto M, Itai T, Yasutake A, Iwasaki T, Yasunaga G, Fujise Y, Nakamura M, Murata K, Chan MH, Domingo $\mathrm{JL}$, Marumoto M. Mercury speciation and selenium in 
toothed-whale muscles. Environ Res 2015;143:55-61.

(100) Li X, Yin D, Yin J, Chen Q, Wang R. Dietary selenium protect against redox-mediated immune suppression induced by methylmercury exposure. Food Chem Toxicol 2014;72C:169-177.

(101) Park SK, Lee S, Basu N, Franzblau A. Associations of blood and urinary mercury with hypertension in U.S. adults: the NHANES 2003-2006. Environ Res 2013;123: 25-32.

(102) He K, Xun P, Liu K, Morris S, Reis J, Guallar E. Mercury exposure in young adulthood and incidence of diabetes later in life: the CARDIA Trace Element Study. Diabetes Care 2013;36:1584-1589.

(103) Ng S, Lin C-C, Hwang Y-H, Hsieh W-S, Liao H-F, Chen P-C. Mercury, APOE, and children's neurodevelopment. Neurotoxicology 2013;37:85-92.

(104) Ng S, Lin C-C, Jeng S-F, Hwang Y-H, Hsieh W-S, Chen P-C. Mercury, APOE, and child behavior. Chemosphere 2015;120:123-130.

(105) Drevnick PE, Lamborg CH, Horgan MJ. Increase in mercury in Pacific yellowfin tuna. Environ Toxicol Chem 2015;34:931-934.

(106) Nakagawa R, Yumita Y. Change and behavior of residual mercury in paddy soils and rice of Japan. Chemosphere 1998;37:1483-1487.

（107）大島晴美, 上野英二, 斎藤 勲, 松本 浩. 玄米打 よび魚介類中カドミウム，鉛，水銀，七素，七レン， マンガン，銅および亜鉛の分析に沶ける誘導結合プ ラズマ質量分析法と原子吸光光度法の比較. 食品衛 生学雑誌 2004;45:270-276.

(108) Kido M, Yustiawati Syawal MS, Sulastri, Hosokawa T, Tanaka S, Saito T, Iwakuma T, Kurasaki M. Comparison of general water quality of rivers in Indonesia and Japan. Environ Monit Assess 2009;156:317-329.

(109) Yorifuji T, Debes F, Weihe P, Grandjean P. Prenatal exposure to lead and cognitive deficit in 7- and 14-year-old children in the presence of concomitant exposure to similar molar concentration of methylmercury. Neurotoxicol Teratol 2011;33:205-211.

(110) Myers GJ, Davidson PW, Watson GE, van Wijngaarden E, Thurston SW, Strain JJ, Shamlaye CF, Bovet P. Methylmercury exposure and developmental neurotoxicity. Bull World Health Organ 2015;93:132-133.

(111) Debes F, Weihe P, Grandjean P. Cognitive deficits at age 22 years associated with prenatal exposure to methylmercury. Cortex 2016;74:358-369.

(112) Tanaka H, Tsukuma H, Oshima A. Long-term prospective study of 6104 survivors of arsenic poisoning during infancy due to contaminated milk powder in 1955. J Epidemiol 2010;20:439-445.

(113) Jensen AR. Genetics and Education. New York: Harper \& Row Publishers, 1972.

(114) Kaufman AS, Kaufman NI. Kaufman Assessment Battery for Children Interpretive Manual. Circle Pines, MN: American Guidance Service, 1983.

(115) Lange RT. Performance IQ. Encyclopedia of Clinical Neuropsychology. New York, NY: Springer, 2011;1907-
1908.

(116) Wechsler D. Wechsler Intelligence Scale for ChildrenThird Edition (WISC-III). San Antonio, TX: Psychological Corporation, 1991.

(117) Tatsuta N, Nakai K, Satoh H, Murata K. Impact of the Great East Japan Earthquake on child's IQ. J Pediatr 2015;167:745-751.

(118) Boucher O, Muckle G, Jacobson JL, Carter RC, KaplanEstrin M, Ayotte P, Dewailly É, Jacobson SW. Domainspecific effects of prenatal exposure to PCBs, mercury, and lead on infant cognition: results from the Environmental Contaminants and Child Development Study in Nunavik. Environ Health Perspect 2014;122:310-316.

(119) Robin AL. ADHD in Adolescents: Diagnosis and Treatment. New York: Guilford Press, 1998.

（120）苗村育郎. 自殺の内景一若者の心と人生. 秋田：無 明舎出版, 2015 .

(121) Ramirez GB, Cruz MCV, Pagulayan O, Ostrea E, Dalisay C. The Tagum Study I: analysis and clinical correlates of mercury in maternal and cord blood, breast milk, meconium, and infants' hair. Pediatrics 2000;106:774-781.

(122) Foldspang A, Hansen JC. Dietary intake of methylmercury as a correlate of gestational length and birth weight among newborns in Greenland. Am J Epidemiol 1990;132:310 317.

(123) Rushton L. Reporting of occupational and environmental research: use and misuse of statistical and epidemiological method. Occup Environ Med 2000;57:1-9.

(124) Herman HG, Miremberg H, Nini N, Feit H, Schreiber L, Bar J, Kovo M. The effects of maternal smoking on pregnancy outcome and placental histopathology lesions. Reprod Toxicol (DOI: 10.1016/j.reprotox.2016.05.022).

(125) Yaginuma-Sakurai K, Murata K, Shimada M, Nakai K, Kurokawa N, Kameo S, Satoh H. Intervention study on cardiac autonomic nervous effects of methylmercury from seafood. Neurotoxicol Teratol 2010;32:240-245.

(126) Ruus A, Øverjordet IB, Braaten HF, Evenset A, Christensen G, Heimstad ES, Gabrielsen GW, Borgå K. Methylmercury biomagnification in an Arctic pelagic food web. Environ Toxicol Chem 2015;34:2636-2643.

(127) Ralston NV, Ralston CR, Raymond LJ. Selenium health benefit values: updated criteria for mercury risk assessments. Biol Trace Elem Res 2016;171:262-269.

(128) Gilman CL, Soon R, Sauvage L, Ralston NV, Berry MJ. Umbilical cord blood and placental mercury, selenium and selenoprotein expression in relation to maternal fish consumption. J Trace Elem Med Biol 2015;30:17-24.

(129) Usuki F, Fujimura M. Decreased plasma thiol antioxidant barrier and selenoproteins as potential biomarkers for ongoing methylmercury intoxication and an individual protective capacity. Arch Toxicol 2016;90:917-926.

(130) Choi AL, Budtz-Jørgensen E, Jørgensen PJ, Steuerwald U, Debes F, Weihe P, Grandjean P. Selenium as a potential protective factor against mercury developmental neurotoxicity. Environ Res 2008;107:45-52.

(131) Sakamoto M, Yasutake A, Kakita A, Rhufuku M, Chan HM, Yamamoto M, Oumi S, Kobayashi S, Watanabe C. 
Selenomethionine protects against neuronal degeneration by methylmercury in the developing rat cerebrum. Environ Sci Technol 2013;47:2862-2868.

(132) Sakamoto M, Murata K, Kubota M, Nakai K, Satoh H. Mercury and heavy profiles of maternal and umbilical cord RBCs in Japanese population. Ecotoxicol Environ Saf 2010;73:1-6.

(133) Odumo BO, Carbonell G, Angeyo HK, Patel JP, Torrijos M, Rodriguez Martin JA. Impact of gold mining associated with mercury contamination in soil, biota sediments and tailings in Kenya. Environ Sci Pollut Res 2014;21:1242612435 .
(134) Guimaraes JR, Betancourt O, Miranda MR, Barriga R, Cueva E, Betancourt S. Long-range effect of cyanide on mercury methylation in a gold mining area in southern Ecuador. Sci Total Environ 2011;409:5026-5033.

(135) http://www.icohweb.org/site_new/multimedia/newsletter/ pdf/icoh_newsletter_vol12_no1.pdf (2016.4.1)

(136) Køster-Rasmussen R, Westergaard ML, Brasholt M, Gutierrez R, Jørs E, Thomsen JF. Mercury pollution from small-scale gold mining can be stopped by implementing the gravity-borax method: a two-year follow-up study from two mining communities in the Philippines. New Solut 2016;25:567-587. 